This item was submitted to Loughborough's Research Repository by the author.

Items in Figshare are protected by copyright, with all rights reserved, unless otherwise indicated.

\title{
Conditioning temperature-index model parameters on synoptic weather types for glacier melt simulations
}

PLEASE CITE THE PUBLISHED VERSION

http://dx.doi.org/10.1002/hyp.10217

\section{PUBLISHER}

(c) John Wiley \& Sons, Ltd.

\section{VERSION}

AM (Accepted Manuscript)

\section{PUBLISHER STATEMENT}

This work is made available according to the conditions of the Creative Commons Attribution-NonCommercialNoDerivatives 4.0 International (CC BY-NC-ND 4.0) licence. Full details of this licence are available at: https://creativecommons.org/licenses/by-nc-nd/4.0/

\section{LICENCE}

CC BY-NC-ND 4.0

\section{REPOSITORY RECORD}

Matthews, Tom K.R., Richard Hodgkins, Robert L. Wilby, S. Gumundsson, F. Palsson, H. Bjornsson, and S. Carr. 2019. "Conditioning Temperature-index Model Parameters on Synoptic Weather Types for Glacier Melt Simulations". figshare. https://hdl.handle.net/2134/16271. 
NOTICE: this is the author's version of a work that was accepted for publication in Hydrological Processes.

Changes resulting from the publishing process, such as peer review, editing, corrections, structural formatting, and other quality control mechanisms may not be reflected in this document. Changes may have been made to this work since it was submitted for publication. A definitive version was subsequently published in:

Matthews, T., Hodgkins, R., Wilby, R.L., Guomundsson, S., Palsson, F., Bjornsson, H. and Carr, S. 2014. Conditioning temperature-index melt model parameters on synoptic weather types. Hydrological Processes, doi: 10.1002/hyp.10217.

which has been published in final form at:

http://onlinelibrary.wiley.com/doi/10.1002/hyp.10217/abstract

This article may be used for non-commercial purposes in accordance with Wiley Terms and Conditions for self-archiving. 


\section{Conditioning temperature-index model parameters on synoptic \\ 3 weather types for glacier melt simulations}

4

5

6 Matthews $^{1}$, T., Hodgkins ${ }^{2}$, R., Wilby ${ }^{2}$, R.L., Guðmundsson ${ }^{3}$, S., Pálsson ${ }^{3}$, F., Björnsson ${ }^{3}$, H., 7 Carr ${ }^{4}$, S.

8

9

$10 \quad{ }^{1}$ Department of Geography, National University of Ireland, Maynooth

$11 \quad{ }^{2}$ Department of Geography, Loughborough University, UK

$12{ }^{3}$ Institute of Earth Science, University of Iceland, Iceland

$13 \quad{ }^{4}$ School of Geography, Queen Mary University of London, UK

14

15

16 Corresponding author:

17 Tom Matthews

18 Department of Geography

19 National University of Ireland

20 Maynooth

21 Kildare

22 Republic of Ireland

23 e-mail: tom.matthews@nuim.ie 


\section{Abstract}

31 Temperature-index models are widely favoured as a pragmatic means of simulating glacier 32 melt due to their generally good performance, computational simplicity, and limited demands 33 for in-situ data. However, their coefficients are normally treated as temporally stationary, 34 unrealistically assuming a constancy of the prevailing weather. We address this simplification 35 by prescribing model coefficients as a function of synoptic weather type, in a procedure that 36 utilizes reanalysis data and preserves the minimal data requirements of temperature-index models. Using a cross-validation procedure at Vestari Hagafellsjökull, Iceland, and Storglaciären, Sweden, we demonstrate that applying transient model coefficients, for three temperature-index models, results in statistically-significant increases in the skill with which melt is modelled, achieving median simulation improvements in the Nash-Sutcliffe Efficiency Coefficient of $7.3 \%$ and $23.6 \%$ when hourly and daily melt totals are evaluated, respectively. Our weather-type modelling approach also yields insight to processes driving parameter variability, revealing dependencies which are consistent with a priori considerations of the Surface Energy Balance. We conclude that incorporating weather types into temperature-index models holds promise for improving their performance as well as enhancing understanding variability in coefficient values. 


\section{Introduction and Aims}

Melting snow and ice has far-reaching and important societal consequences, not least for water and energy security of communities. Physically, the consumption of latent heat, decline in surface albedo and impact on the hydrological cycle caused by this phase change has implications for the Earth-atmosphere system as a whole. Quantifying glacier melt rates has, therefore, received much attention, with particular focus on modelling studies.

Generally, models calculate the melt rate either from principles of energy conservation (energy balance models), or from empirical associations between meteorological variables and surface melting. Most commonly, empirical formulations exploit the correlation between melt and air temperature (temperature-index models). Whilst a physical approach to melt modelling is conceptually desirable, it is often impractical to apply in practice, due to the detailed knowledge of the local micrometeorology and snow/ice surface properties demanded.

Empirical, temperature-based melt models have less stringent data requirements. Measurements of air temperature are widely available and this variable is also relatively straightforward to interpolate and forecast (Hock, 2003). Despite their simplicity, temperature-index approaches also generally perform well in melt simulations-often matching or exceeding the skill of energy balance models (Hock, 2005; Zhang et al., 2012). Thus, temperature-index models are applied widely in cryospheric research, and notably in assessing, likely future melt rates for the world's glaciers (Raper and Braithwaite, 2006; Radić and Hock, 2011; Marzeion et al., 2012; Dobler et al., 2012). Because rising air temperature are one of the most likely consequences of anthropogenic climate change (Meehl et al., 2007; Maraun et al., 2010), these models are conceptually well placed for such application.

At their most basic, temperature-index models take the general form (e.g. Hodgkins, 2012):

$$
M= \begin{cases}M F_{\text {snow } / \text { ice }} \mathrm{T} & : \mathrm{T}>T_{c} \\ 0 & : \mathrm{T} \leq T_{c}\end{cases}
$$

where $T$ is air temperature $\left({ }^{\circ} \mathrm{C}\right)$, and $T_{c}$ is a threshold air temperature, above which melting occurs at a rate governed by the melt factor $(M F)$. The subscripts indicate that different values are applicable, depending on whether the melting surface is snow or ice. Time periods 
of a day are frequently used for the relation described by Eq. (1): $T$ is then averaged to daily resolution and the $M F$ has units of mm w.e. ${ }^{\circ} \mathrm{C}^{-1} \mathrm{~d}^{-1}$. If a threshold of $0^{\circ} \mathrm{C}$ is defined, the $M F$ is usually termed the 'degree-day factor' $(D D F)$ and air temperatures over $T_{c}$ are known as 'positive degree days’ (PDDs: Hock, 2003).

More elaborate empirical formulations are provided by enhanced temperature-index models (ETIs) (Cazorzi and Dalla Fontana, 1996; Hock, 1999; Daly et al., 2000; Pellicciotti et al., 2005), which typically include a term to reflect changes in the shortwave radiation balance the dominant source of melt energy for most alpine glaciers (Willis et al., 2002). ETI models outperform traditional approaches (e.g. Eq. 1) in inter-comparison studies by better accounting for spatial and temporal variability in melt rates (Cazorzi and Dalla Fontana, 1996; Hock, 1999; Pellicciotti et al., 2005).

Whilst provision for changes in the shortwave heat flux common to ETI models offers both a conceptual and practical improvement to temperature-index melt simulations, they have some important limitations. ETIs and their more basic counterparts usually employ temporallystatic coefficients. With regard to the $D D F$, this treatment has long been recognized as physically unrealistic (Lang and Braun, 1990, Braithwaite, 1995; Hock, 2003), as its value depends on the SEB, and hence, on the prevailing weather. Carenzo et al. (2009) confirmed that the same is true of parameters in the Pellicciotti et al. (2005) ETI model. More recently, Carturan et al. (2012) and Irvine-Fynn et al. (2014) also highlighted the role of variable weather types as possibly responsible for the limited interannual transferability of calibrated ETI model parameters.

To reduce the detrimental effect of parameter sensitivity to weather types, Lang and Braun (1990) recommended extensive periods of integration to calibrate $D D F$ s to obtain values more appropriate for sites' 'average weather'. This same reasoning can be extended to the calibration of parameters within ETI models. However, as interannual synoptic variability can be high in mid- and high-latitudes (Fettweis et al. 2011), in practice, it may be challenging to identify calibration periods representative of long-term average conditions. Moreover, in the context of climate change 'average weather' is not expected to be stationary, making this calibration philosophy questionable for simulations of future glacier melt.

A more conceptually appealing approach to temperature-index melt modelling would be to account for the effect of different weather types on parameters explicitly, by prescribing 
116 transient values appropriate to the prevailing weather. However, provisioning for the effect of 117 weather types on model parameters implies a need for additional knowledge of local 118 micrometeorology. Such information is not necessarily available in remote locations typical 119 of glacierized regions. Thus, practical steps to integrate the effect of weather types on

120 temperature-index model parameters should seek to preserve their low demands for in-situ 121 data.

122 In this study we show how the effect of weather types on temperature-index model 123 parameters can be incorporated without the need for additional meteorological measurements 124 from the glacier boundary layer. To achieve this, temperature-index models are conditioned on synoptic weather types derived from gridded climate data. The skill of weather-typedependent models is assessed relative to unmodified temperature-index models. Variation in model parameters between weather types is also explored to gain insight to meteorological controls on their temporal evolution.

\section{Data and Methods}

130 Conditioning temperature-index model parameters by weather type requires high-resolution

131 information on glacier melt rates and the prevailing meteorology. Details of these datasets are 132 provided in this section, along with a description of the procedure for defining weather types 133 and the process for evaluating the utility of transient model parameters.

\section{$134 \quad$ 2.1. Glacier melt rates}

135 Our data are obtained from Vestari Hagafellsjökull, Iceland, and Storglaciären, Sweden. Melt 136 rates from both glaciers are determined from SEB simulations conducted with an energy 137 balance model. We use these data, rather than melt estimates from measurements at ablation 138 stakes or acoustic sounders, because the latter can be prone to substantial error when 139 converting to water equivalent melt totals at high temporal resolutions typical of ETI models 140 (Müller and Keeler, 1969; Munro, 1990; Arendt and Sharp, 1999; Pellicciotti et al., 2005).

141 The meteorological measurements and SEB calculations are described in detail by Matthews 142 (2013) and are summarised here. Ablation-season meteorological observations on Vestari 143 Hagafellsjökull (Langjökull) have been logged hourly by automatic weather stations (AWSs) 144 installed by the Institute of Earth Sciences, University of Iceland in 2001. One station is 145 located in the lower ablation zone at 500 m.a.s.l (VH 500) and the other at 1100 m.a.s.l (VH 
146 1100), the approximate elevation of Langjökull's average equilibrium line altitude. In this 147 study, data are used from June-August 2001-2007 at VH 500 and from 2001-2009 at VH 148 1100. Sensor specifications are provided in Table 1, and further details of the measurement 149 campaign can be found in Guðmundsson et al. (2009).

150 At Storglaciären, detailed AWS observations were made in the upper ablation area ( 1387 151 m.a.s.l) on the glacier during July-August 2011 (Figure 1), and more limited data acquisition 152 took place in 2010 (Table 1). Interannual variability in the SEB can be pronounced at 153 Storglaciären, as a result of differing weather conditions (Hock and Holmgren, 2005). Thus, 154 we consider it valuable to extend this two-season record, to sample a wider variety of 155 meteorological conditions. Extending our record of glacier-meteorology is made possible due to the proximity of the Tarfala Research Station (TRS), situated $\sim 1 \mathrm{~km}$ from the glacier terminus in the valley bottom.

158 Despite the proximity of TRS to our study site, its location outside the glacier boundary layer means that judicious adjustment of measured data is required to infer glacier meteorology.

160 The empirical functions applied by Matthews (2013) are therefore used to adjust hourly mean 161 values of air temperature, vapour pressure, wind speed, and the incident shortwave flux 162 recorded at TRS, to the location of the glacier-based AWS. The incident longwave flux is not 163 measured at TRS, so it is determined for the glacier site following the expressions of Sedlar and Hock (2009). Albedo is assumed invariant outside the period of glacier-based observations and is prescribed as the mean ice albedo obtained from measurements (0.38). This treatment neglects any changes in surface reflectivity or roughness that may result from snowfall.

168 Parameterized meteorological series are used to infer glacier meteorology for periods when 169 direct observations unavailable in June and August, 2005-2011 (Table 2). 2005 is chosen as 170 the earliest year from which to use TRS data because of heterogeneity in the shortwave 171 radiation record prior to this date (Matthews, 2013). Further information regarding the 172 meteorological measurement campaign at TRS can be found in Grudd and Schneider (1996) 173 and Jonsell et al. (2013).

174 A summary of agreement between the meteorology observed on-glacier and that 175 parameterized from the TRS data is shown in Table 3 using the Nash-Sutcliffe Efficiency 176 Coefficient $\left(R^{2}\right.$ : see Section 2.3). With the exception of hourly means of wind speed and 
177 incident longwave radiation, correspondence between series is encouraging. However, due to 178 the imperfect fit, use of these data in our energy balance simulation introduces error to our reference melt series which will propagate to our temperature-index melt simulations.

180 Details of SEB computations for both sites are provided in Table 4. Models are validated by comparing simulated cumulative water equivalent melt with totals estimated from observations of surface lowering, which is converted to water equivalent through the empirical formulation outlined in Hodgkins et al. (2012). Using plausible values of the surface roughness length for momentum, taken from previous investigations at our study sites (Guðmundsson et al., 2009; Hock and Holmgren, 1996), our energy balance models are able to simulate melt totals, which, within estimates of their uncertainty, agree with observations (Figure 2). No tuning of model parameters (e.g. roughness lengths) was therefore considered necessary.

No direct observations of surface lowering are available at our study site on Storglaciären prior to 2011 (when the SEB model is forced with the parameterized meteorological series from TRS); hence validation of model performance is not possible for this period. To investigate the effect of using this series, rather than the observations made at the glacier AWS, we can compare SEB model results when simulations are forced by both series for the period when glacier observations are available (Figure 3). The good overall correspondence between melt simulated with these series provides confidence in the utility of using the parameterized TRS data to extend our reference melt series. With the addition of the melt rates calculated from adjusted TRS data, the reference melt series constitutes 434 days at

198 Storglaciären; the records from VH 500 and VH 1100 comprise 644 and 828 days, respectively. All these lengths are denoted $N$ hereafter. Summaries of the meteorology and calculated energy components for the respective locations over these periods are provided in Table 4.

\subsection{Reanalysis data}

203 We use gridded reanalysis data (ERA-Interim) to determine synoptic weather types (Dee et 204 al., 2011). The variables chosen to categorize daily weather are: two-metre air temperature $205\left({ }^{\circ} \mathrm{C}\right)$; two-metre dewpoint air temperature $\left({ }^{\circ} \mathrm{C}\right)$; ten-metre $\mathrm{U}$ component of wind speed ( $\mathrm{m} \mathrm{s}^{-}$ $20{ }^{1}$ ); ten-metre $\mathrm{V}$ component of wind speed $\left(\mathrm{m} \mathrm{s}^{-1}\right.$ ); total cloud cover (fraction); and sea level 207 air pressure $(\mathrm{Pa})$. These include most of those variables chosen frequently to characterise the 208 prevailing meteorology in weather-type/air-mass identifications (e.g. Kalkstein and Corrigan, 
1986; Sheridan, 2002; Fealy and Sweeney, 2007; Bower et al., 2007). The reanalysis data were obtained at six-hourly resolution from grid cells overlying the field sites.

211 The selected variables were transformed to z-scores and subject to a Principal Components 212 Analysis (PCA). Five Principal Components (PCs) were retained accounting for $>80 \%$ of the 213 variance in the original variables. The six-hourly reanalysis meteorology and PC loadings 214 were then used to determine daily PC scores following Kalkstein and Corrigan (1986). These 215 PC scores are used to identify periods of comparable weather in the algorithm described 216 below (Section 2.4).

\subsection{Temperature-index models}

218 Three temperature index models are deployed to investigate the utility of using melt 219 parameters conditioned by synoptic weather types. The first is the basic melt formulation outlined in Eq. 1, referred to as Model 'A' hereafter. The others are ETI models, namely the algorithms of Hock (1999) (hereafter model 'B'), and Pellicciotti et al. (2005) (hereafter model ' $C$ '). Our choice of models includes those used most frequently for purposes of glacier melt modelling, while differences in structure and data requirements facilitates insight into how our weather-type approach may contribute to more robust and accurate temperatureindex melt simulations.

Model B has the form:

and model C is:

230 Where $M$ is melt ( $\mathrm{mm}$ w.e. $\mathrm{hr}^{-1}$ ), $T M F$ is the temperature melt factor ( $\mathrm{mm}$ w.e. ${ }^{\circ} \mathrm{C}^{-1} \mathrm{~h}^{-1}$ ), $\mathrm{T}$ is 231 two-metre air temperature $\left({ }^{\circ} \mathrm{C}\right), R T M F$ is the radiation-temperature melt factor (mm w.e. $\mathrm{W}^{-1}$ $232 \mathrm{~m}^{2}{ }^{\circ} \mathrm{C}^{-1} \mathrm{~h}^{-1}$ ), $R M F$ is the radiation melt factor ( $\mathrm{mm}$ w.e. $\mathrm{W}^{-1} \mathrm{~m}^{2} \mathrm{~h}^{-1}$ ), $\alpha$ is albedo 233 (dimensionless) and $I_{o / p}$ is incident global radiation. The subscripts for this term relate to the 234 fact that we run models A and B using actual global radiation measured/parameterized at the glacier AWSs $\left(I_{o}\right)$, and using potential, clear-sky radiation $\left(I_{p}\right)$ which is determined for our sites using standard equations of solar geometry (Oke, 1987), and includes the effects of shading, slope and exposition. To facilitate these calculations, topographic information from 
the Koblet et al. (2010) DEM for Storglaciären and from the ASTER GDEM for Vestari Hagafellsjökull is used. Similar to Eq. 1, models B and C only permit melting when the hourly air temperature is above a threshold, which we assume to be $0^{\circ} \mathrm{C}$.

241 The albedo required in Eqs. 2 and 3 is taken directly from observed/prescribed values at the 242 locations of the glacier AWSs. Whilst this likely results in a favourable performance of 243 models B and C, our aim does not include the assessment of empirical schemes for simulating 244 albedo: using values retrieved from the AWSs enables greater focus on addressing the variability of temperature-index model parameters between weather types. The models are run with an hourly time step and all the driving meteorological variables are taken from hourly observations made at, or parameterized for, the glacier AWSs (Section 2.1).

248 Coefficients are calibrated for five models (three algorithms; B and C are implemented with 249 both observed, and clear-sky global radiation) with optimal values determined using the 250 Nash-Sutcliffe Efficiency Coefficient (Nash and Sutcliffe, 1970):

$$
R^{2}=1-\sum_{i=1}^{i=h} \frac{\left(M_{r i}-M_{S i}\right)^{2}}{\left(M_{r i}-\overline{M_{r i}}\right)^{2}}
$$

where $M$ is the melt rate and subscripts $r$ and $s$ denote the reference series (calculated with the SEB models), and melt simulated by the temperature-index model, respectively. The over-bar in Eq. 4 indicates the mean, and $h$ gives the number of melt values for which to evaluate goodness of fit between reference and simulated values. The objective function, 1$R^{2}$, is minimized using the Nelder-Mead Simplex algorithm to find optimal values for model coefficients. The algorithm is implemented via the Matlab 'fminsearch' function and Eq. 4 is calculated for hourly melt rates.

\subsection{Temporally-variable model coefficients}

260 The core of the technique investigated is to identify meteorologically-similar days from 261 spatially-coarse reanalysis data, and to vary temperature-index model coefficients accordingly. Similarity of weather between days is judged using the PC scores described in Sect. 2.2. For any pair of days $\left(\mathbf{D}_{\boldsymbol{t}}\right.$ and $\left.\mathbf{D}_{w}\right)$, this is quantified according to:

$$
\delta\left(\mathbf{D}_{t}, \mathbf{D}_{\boldsymbol{w}}\right)=\sqrt{\sum_{i=\mathbf{1}}^{q}\left(v_{t i}-v_{w i}\right)^{2}}
$$


where $v$ is the vector of PC scores with $q$ dimensions; here $q=5$, because the first five PCs were retained to describe daily meteorology. Calculating $\delta\left(\mathbf{D}_{\boldsymbol{t}}, \mathbf{D}_{\boldsymbol{w}}\right)$ means that archived days can be ranked according to their similarity to the prevailing meteorology. This approach underpins the nearest-neighbour resampling techniques often used to synthesize climate series from historical observations (e.g. Young, 1994; Beersma and Buishand, 2003). Here the method is used to identify periods with similar meteorological conditions to condition temperature-index model parameters.

The utility of this technique is determined through a cross-validation procedure, implemented at each location as follows:

1) For every day, $\delta\left(\mathbf{D}_{t}, \mathbf{D}_{w}\right)$ is calculated between the present day and all other days from other years. Only days from other years are considered in application of Eq. (5), because a condition of cross-validation schemes is that the simulated data should be independent of that used for calibration (Elsner and Schmertmann, 1994). To avoid autocorrelation within the melt series compromising the crossvalidation, data from the same year as the day being simulated are excluded from the fitting procedure.

2) The $\delta\left(\mathbf{D}_{\boldsymbol{t}}, \mathbf{D}_{\boldsymbol{w}}\right)$ measure is used to rank all days evaluated in step one.

3) Using the reference melt series and Eq. 4, all coefficients for each temperatureindex model are calibrated on the $k$ most similar days to the present.

4) The present day's melt is simulated at hourly resolution using the respective algorithms and the coefficient estimates obtained in step three.

Thus, all parameters for the five models are calculated $N$ times for every location, using the $k$ most meteorologically similar days for calibration.

The choice of $k$ in the algorithm is evidently important. Previous research employing nearestneighbour resampling suggests that setting $k=n^{1 / 2}$ yields favourable results, provided that the number of potential neighbours, $n$, is at least 100 and $q \leq 6$ (Lall and Sharma, 1996). In our cross-validation scheme, $n$ is simply the number of days which are compared to each day on which melt is simulated, so our data satisfy these criteria ( $n$ is 552, 736 and 372 at VH 500, VH 1100 and Storglaciären, respectively). Parameter $k$ is, therefore, set to the nearest integer of $n^{1 / 2}$ in the algorithm (23, 27 and 19, respectively). 
295 Model A requires that only days of the same glacier surface type are considered for calibrating model coefficients, so at each site, only such days are evaluated for meteorological similarity in step 1 of our algorithm. This means that $n$ is dynamic for this model, depending on the number of days of comparable surface type in the other years (identified from the albedo record: Figure 4). Because snow cover is rare at two of our sites (VH 500 and Storglaciären), this sometimes results in $n$ falling below the 100-day threshold outlined above, so the choice of $k$ may be inappropriate for these days. However, this effect is anticipated to have a minimal effect on simulations as the majority of the series at these locations (94\% and 89\%, respectively) is modelled with coefficients estimated for days which satisfy the threshold for prescribing $k$ (i.e. those days not designated as snow).

The cross-validation procedure is also run to estimate the skill of the models when coefficients do not reflect weather type variations. This means that, for every day, coefficients are simply calibrated using all data in the remaining years, irrespective of meteorological similarity. This results in coefficient estimates which only vary between years. For each of the models we therefore have two melt series generated via the crossvalidation procedure: one simulated with coefficients that vary daily with the prevailing synoptic weather types (hereafter the ' $W T$ ' series), and the other simulated with coefficients that only vary inter-annually (hereafter the ' $S$ ' series). Evaluating both series' correspondence with the reference melt record (Eq. 4), and comparing performance, provides insight into the value-added by the weather-type calibration routine.

The significance of any improvement in skill is assessed using a bootstrap simulation, implemented by selecting observations from both series on $m$ randomly chosen days, and evaluating their correspondence with reference series on these days. The bootstrap is run with $10^{4}$ samples, and $m$ is set to the number of days in one year's melt record at our study glaciers (92 and 62 days at Vestari Hagafellsjökull and Storglaciären, respectively). For each of the models, counting the number of times the WT series exhibits greater correspondence with the reference melt record than the $S$ series (according to Eq. 4) and dividing this count by $10^{4}$, provides an estimate of the probability of not obtaining an increase in seasonal melt simulation using our approach (Wilmott, 1985). We evaluate all models in terms of their ability to simulate both hourly and daily melt totals.

The cross-validation procedure also generates an $N$-member ensemble of coefficient estimates for each model at each location. Examining these series in relation to the prevailing 
glacier meteorology provides a diagnostic of processes behind the model coefficients' variability. This is pursued by correlating the daily coefficient values for each of the five models with daily mean meteorological variables and components of the SEB determined at the AWSs. Correlating model coefficients between locations on Vestari Hagafellsjökull also permits insight into the spatial coherence of their variability in response to synoptic weather types.

\section{Results}

\section{4 \\ 3.1 Model Performance}

The results of applying the five models are illustrated in Figures 5 and 6, while performance measures for each site are shown in Table 6. The best performances are registered by the ETI models forced with observed global radiation, and Model C generally scores higher $R^{2}$ values than Model B. Model A performs relatively poorly at hourly resolution, but performs better relative to ETI models when evaluated at daily resolution. Model B suffers the greatest reduction in skill, and the range in performance between locations is also larger for all models when examined at daily time scales. Irrespective of whether hourly or daily melt rates are examined, the performance of the models is on average best at Storglaciären, and worst at VH 500.

Across all models, the WT series exhibit greater correspondence with reference melt series, registering median improvements (with respect to the $S$ series) of $7.3 \%$ and $23.6 \%$ in the simulation of hourly, and daily melt rates, respectively. There is no clear pattern with regards which model registers the most improvement when calibrated with respect to weather types, but there is a general tendency for the magnitude of improvement to be inversely related to performance of the unmodified temperature-index model (Figure 7). An example of the output from the bootstrap procedure is shown in Figure 8 and the full results are recorded in Table 5. The probability of not obtaining an enhancement in a seasonal melt simulation using the weather-type approach to calibrate model coefficients is low for all models $(p<0.05)$ for all locations.

\subsection{Model Coefficients}

Mean coefficient values obtained for each model during cross-validation, and their respective coefficients of variation $(\sigma / \mu * 100)$, are shown in Table 7. Estimates of $M F_{\text {snow/ice }}$ (Model 
357 A) range between $0.285 \mathrm{~mm}$ w.e. ${ }^{\circ} \mathrm{C}^{-1} \mathrm{~h}^{-1}$ and $0.685 \mathrm{~mm}$ w.e. ${ }^{\circ} \mathrm{C}^{-1} \mathrm{~h}^{-1}$ for the $W T$ and $S$ series, 358 with universally higher values observed for ice surfaces. These estimates are within the 359 bounds reported in the literature (e.g. Hock, 2003). For the ETI models, TMF values between $360 \quad 0.107 \mathrm{~mm}$ w.e. ${ }^{\circ} \mathrm{C}^{-1} \mathrm{~h}^{-1}$ and $0.231 \mathrm{~mm}$ w.e. ${ }^{\circ} \mathrm{C}^{-1} \mathrm{~h}^{-1}$ are observed, and values of $R M F$ and $361 \quad R T M F$ fall between 0.0010 (RTMF: mm w.e. $\left.\mathrm{W}^{-1} \mathrm{~m}^{2}{ }^{\circ} \mathrm{C}^{-1} \mathrm{~h}^{-1}\right)$ and $0.0105\left(R M F\right.$ : $\mathrm{mm}$ w.e. $\mathrm{W}^{-}$ $362{ }^{1} \mathrm{~m}^{2} \mathrm{~h}^{-1}$ ). These values are also in general agreement with those reported in the literature 363 (Hock, 1999; Carturan et al., 2012; Irvine-Fynn et al., 2014).

364 Between weather types, $T M F$ is the most variable coefficient whilst $R M F$ in Model C is the 365 least variable, particularly when this model is forced by observed global radiation. For both 366 ETI models radiation coefficients are more stable when the observed flux is used in the cross 367 validation procedure. Figure 9 highlights the variability of model coefficients around the 368 globally-optimum coefficient values observed during the cross-validation procedure for the 369 ETI models (see Figure 9 caption). Model B generally exhibits greater departure from these 370 optimum values highlighting the need for a larger adjustment of ETI model values to account 371 for the prevailing weather in Model B, than in Model C. Figure 9 also demonstrates the 372 interdependency of temperature and radiation parameters in the ETI models that is evident for 373 the entire dataset (shown by the slope in the contour field), but that is particularly apparent 374 between weather types (shown by the linear relation evident in the scatter plot). Only when 375 Model C is driven by observed global radiation, do the temperature and radiation coefficients 376 appear to vary independently between weather types, which results from the stability of the $377 R M F$ term. Models driven by potential global radiation show most pronounced 378 interdependence of model coefficients between weather types.

379 The cause of variability in model coefficients between weather types was explored by 380 correlating values obtained for each model in the cross-validation procedure with daily mean 381 values of the prevailing meteorology/SEB components for the locations of the AWSs (Figure 382 10). TMF values exhibit consistency in their correlations between models and locations, 383 being positively correlated with the turbulent and longwave heat fluxes, and negatively 384 correlated with the shortwave heat flux. Consistent with the these associations, Figure 10 385 indicates $T M F$ coefficients exhibit the strongest positive correlations with cloud cover and 386 vapour pressure, and weaker positive correlations with air temperature and wind speed. 
$R M F$ and RTMF exhibit similar correlations with the prevailing meteorology and SEB between locations, which are somewhat opposite in sign to the those observed for TMFs. Both $R M F$ and $R T M F$ correlate positively with the shortwave heat flux and negatively with the longwave heat flux and cloud cover. These correlations are typically stronger for the models forced with potential global radiation, particularly for $R M F$. Correlations for $M F_{\text {snow/ice }}$ show a high degree of similarity to those recorded for the radiation melt factors, especially those observed for $R T M F . M F_{\text {snow }}$ at $\mathrm{VH} 500$ is an exception, exhibiting correlations very similar to those obtained for the $T M F \mathrm{~s}$ at this location.

The difference in correlations with the SEB and prevailing meteorology observed for $M F_{\text {snow }}$ between elevations on Vestari Hagafellsjökull results in little temporal correspondence between these coefficient estimates (Figure 11). For all the other coefficients, their daily values are positively correlated between elevations. The strongest agreement is for the TMF coefficients. For both $R M F$ and $R T M F$, those models forced by potential global radiation are more strongly correlated between locations.

\section{Discussion}

\subsection{Model Performance and Coefficient Variability}

At all locations, and for all models, our weather-type approach to calibrating parameters significantly improved melt simulations with greatest enhancements apparent for daily melt totals. This is explained by the fact model coefficients in the algorithm described in Section 2.4 vary on a daily timescale depending on synoptic weather type. Thus, sub-daily variability in coefficients cannot be accounted for. The observation that weather-type conditioning resulted in larger improvements for models more limited in initial skill, demonstrates greater benefit of applying our modelling approach where temperature-index methods are more limited in their ability to capture processes of surface energy exchange.

411 Correlations between parameters from the WT series and the prevailing meteorology provide

412 insight to the value added by weather-type conditioning. TMF coefficients in all models were 413 found to be correlated most strongly with latent and longwave heat fluxes. This can be 414 understood through consideration of the SEB, as these energy components are related to air 415 temperature in a non-linear way, through the Clausius-Clapeyron and Stefan Boltzmann 416 equations, respectively. The former relation also explains the positive correlations observed 
417 between $T M F$ and vapour pressure at all locations. The strong positive association with cloud 418 cover is in agreement with Carenzo et al. (2009). This can be understood through a priori 419 SEB considerations, as the sensitivity of the longwave heat flux to air temperature would be 420 expected to rise as the apparent emissivity of the atmosphere increases (cf. Sedlar and Hock, 421 2009).

422 Consistent with Carenzo et al. (2009) both $R M F$ and RTMF exhibit strongest positive 423 correlations with the net shortwave heat flux. Additionally, these coefficients are generally correlated more strongly with the prevailing meteorology/SEB when models are forced with potential global radiation. This is most notable for correlations with cloud cover and the longwave heat flux (themselves strongly co-linear at each location: minimum $r=0.82$ at Storglaciären). These stronger correlations reflect the fact that no provision is made for temporal variability in atmospheric transmissivity for the models forced with potential global radiation, so this information must be included implicitly in the value of the scalars $R M F$ and $R T M F$. This mechanism also provides an explanation for the reduced variability of the radiation factors in models forced with observed global radiation.

Compared with $R M F, R T M F$ is more variable between weather types irrespective of whether observed or global radiation was used to drive the models. Therefore, Model B was more sensitive to changes in prevailing meteorology consistent with previous interpretations of ETI model errors that have applied this algorithm (Konya et al., 2004; Carturan et al., 2012; Irvine-Fynn et al. 2014). This is possibly an artefact of the physically-unrealistic scaling of the net shortwave heat flux by air temperature (Pellicciotti et al., 2005; Irvine-Fynn et al. 2014). This coupled with the lower model skill generally exhibited by Model B relative to Model C, even when variable weather types were provisioned for, makes the additive structure of the Pellicciotti et al. (2005) algorithm the most attractive of the methods investigated for melt simulation at these glaciers.

Whilst Model A could not be expected to match the performance of the ETI models, there is additional interest in the meteorological controls on the $M F$ given its widespread use for glacier melt modelling under climate change, (e.g. Raper and Braithwaite, 2006; Radic and Hock, 2011). $M F_{\text {ice }}$ exhibited meteorological dependencies similar to those observed for the radiation melt factors of models B and C, with positive and negative correlations apparent for the shortwave and temperature-dependent heat fluxes, respectively. This is consistent with the net shortwave heat flux being the dominant source of melt energy at all locations (Table 
449 5), agreeing with the controls outlined by Hock (2003), and suggesting a relationship similar 450 to that proposed by Irvine-Fynn et al. (2014). $M F_{\text {snow }}$ did not display the same level of 451 agreement with the radiation melt factors in regards to its dependency on the prevailing 452 weather, likely due to reduced importance of net shortwave heat in the SEB as snow cover 453 lowers surface albedo considerably (Figure 4).

454 The value-added to model skill by dynamic model coefficients conditioned on weather types 455 can be attributed to reduction in high-frequency error. Changes in the sensitivity of the 456 temperature-dependent heat fluxes to air temperature, for example, which reflects the effects 457 of variable temperatures, humidities, thermal emissivities and wind speeds can be 458 provisioned for by varying $T M F$. Similarly, the variable sensitivity of the SEB to the net 459 shortwave flux, which varies principally with the magnitude of the incident flux, can also be 460 adjusted. So too can the value of the $M F$, which exhibits dependencies similar to the radiation 461 coefficients in the ETI models. Conditioning by weather types accounts for variations in these 462 parameters by invoking the analogue principle (Kuhn, 1993), which simply assumes that 463 similarity in synoptic weather between days translates to similar on-glacier meteorology and, 464 consequently, similar model coefficients. The processes driving parameter variability do not 465 need to be addressed explicitly.

466 This approach to dynamic parameter allocation may also provide a more conceptually-robust 467 means of integrating climate variability into melt simulations. In order to limit errors from static model coefficients to acceptable levels average weather must stay constant in time; a condition that is unlikely to be satisfied thus rendering calibrated coefficients unsuitable for determining melt rates under changed climate conditions. Studies of atmospheric circulation in the mid- and high-latitudes during the last century have demonstrated considerable nonstationarity in the frequency of air masses/weather types (Bárdossy and Caspary, 1990; 473 Kalkstein et al., 1990; Wilby 1997). In addition, large changes in atmospheric circulation have been noted recently for the glacierized margin of the North Atlantic (Fettweis et al., 2011, 2013 Hanna et al., 2012). Whatever their cause, failure to accommodate changes in the mean weather resulting from variable atmospheric circulation undermines the assumption of static model coefficients. Use of transient model parameters as demonstrated here offers an improved approach to accommodate variability in the frequency of weather types in model calibration explicitly. 
481 It must also be recognized that weather types are prone to differential rates of warming under

482 a changing climate (e.g. Kalkstein et al., 1990). In the northern hemisphere, for example,

483 high-latitude air masses are likely to warm most rapidly due to Arctic amplification (Holland 484 and Bitz, 2003; Serreze et al., 2009). If static temperature-sensitivities are assumed, large 485 errors in simulated melt will manifest if rapid warming occurs in those weather types with 486 sensitivities furthest from the average calibrated coefficients which quantify this association.

487 This potential source of error can be traced by analysing the time-varying parameters 488 associated with individual weather types.

\section{4.2. Study Limitations and Transferability of the Modelling Approach}

490 In interpreting the improvement offered by our weather-type approach to parameter calibration, it is important to consider that our reference melt series are generated by SEB models and these are prone to uncertainty, particularly with regards to estimation of the turbulent heat fluxes (Hock, 2005). Our bootstrapped test of the enhancement provided by the weather-type melt models makes no provision for the fact that their performance is not assessed relative to a 'true' melt rate, and thus the significance of our improvement should be interpreted with caution. This is especially true at Storglaciären, where most of the reference melt series was generated using parameterised TRS data. However, we note that the skill in simulating melt exhibited by the weather-type-dependent models is similar when evaluated relative to the reference melt series in 2011 (where almost all data are taken from glacier AWS observations), as it is in other years (when mainly TRS data are used: Table 8). Thus, whilst the extent of the uncertainty introduced by the parameterised series remains somewhat un-quantified, this assessment at least provides confidence that the improvement in simulation performance achieved at this location does not depend on the use of these offglacier data.

505 A simplification applied in the modelling procedure was to use measured values of albedo to prescribe surface types (Model A) and to obtain the net global radiation (models B and C). It is considered unlikely that this results in bias in the model comparison, as this information would seem equally important for both the weather-type and static models. This issue does however raise an interesting point regarding the transferability of our approach. The SEB is a function of the interaction between the boundary-layer meteorology and the glacier surface.

511 Changing glacier surface conditions (i.e. albedo, surface roughness) introduces variability in 512 melt rate independent of the prevailing weather which cannot be captured using the weather- 
513 type approach. Hence, on glaciers where temporal variability of surface properties is

514 pronounced, more limited benefit might be realised by calibrating parameters with respect to

515 weather types.

516 While our approach offers improved simulations at the point scale, distributing dynamic 517 coefficients across the glacier adds further uncertainty to the modelling procedure. However, 518 considering that variation of the transient model parameters was strongly coherent between 519 elevations on Vestari Hagafellsjökull, the evidence suggests that our approach may be 520 extended to glacier-wide simulations if judicious placement of AWSs is accompanied by 521 interpolation of model parameters over the glacier.

522 The temporal transferability of our modelling approach also demands consideration. Changes 523 in the internal structure of weather types would limit the advantage of our calibration method.

524 If climate change manifests as weather types without precedent during calibration, then this 525 strategy will be compromised. By the same reasoning, it is also likely that our weather-type 526 approach to calibration will be most useful for glaciers where long records of observation are 527 available and the information content of calibration data is maximised (Van den Dool, 1994). 528 Variations in the SEB that may occur with time and which are independent of the prevailing 529 weather (e.g. changes in glacier hypsometry: Braithwaite, 2008) can of course not be 530 accounted for with our calibration strategy.

\section{5. Conclusions}

532 This study evaluated the utility of varying temperature-index model parameters to reflect 533 changes in prevailing weather during melt simulations. Our results indicate that using 534 spatially-coarse reanalysis data to define periods of meteorological similarity for calibrating 535 models significantly enhances the skill of three algorithms commonly-used to simulate site536 specific, glacier melt estimates.

538 The approach also provides insight to the meteorological and energetic controls of model water coefficients. Changes in parameter values between weather types were consistent with expectations from physical considerations of the surface energy balance. Future work should explore climatological controls on temperature-index model parameters with a view to

542 determining the transferability of our approach to other glaciers or to spatially-distributed 543 modelling approaches across large and/or data sparse catchments. 


\section{References}

545 Andreas EL. 1987. A theory for the scalar roughness and the scalar transfer coefficients over

546 snow and sea ice. Boundary-Layer Meteorology 38: 159-184. doi: 10.1007/BF00121562.

547 Arendt A. and Sharp MJ. Energy bal ance measurements on a Canadian high arctic glacier and

548 their implications for mass bal ance modeling. IAHSPublication 256: pp. 165-172.

549 Bárdossy A and Caspary H. 1990. Detection of climate change in Europe by analyzing

550 European atmospheric circulation patterns from 1881 to 1989. Theoretical and Applied.

551 Climatology 42: 155-167. doi: 10.1007/BF00866871.

552 Beersma JJ and Buishand TA. 2003. Multi-site simulation of daily precipitation and 553 temperature conditional on the atmospheric circulation. Climate Research 25: 121-133. doi: 554 10.3354/cr025121.

555 Beljaars ACM and HOLTSLAG AAM. 1991. Flux parameterization over land surfaces for 556 atmospheric models. Journal of Applied Meteorology 30: 327-341. doi: 10.1175/1520557 0450(1991)030<0327:FPOLSF>2.0.CO;2.

558 Bower D, Mcgregor GR, Hannah DM and Sheridan SC. 2007. Development of a spatial 559 synoptic classification scheme for Western Europe. International Journal of Climatology 27: 560 2017-2040. doi: 10.1002/joc.1501.

561 Braithwaite RJ. 1995. Positive degree-day factors for ablation on the Greenland ice sheet 562 studied by energy balance modeling. Journal of Glaciology 41: 153-160.

563 Braithwaite R. 2008. Temperature and precipitation climate at the equilibrium-line altitude of 564 glaciers expressed by the degree-day factor for melting snow. Journal of Glaciology 54: 437565 444. doi: 10.3189/002214308785836968.

566 Carenzo M, Pellicciotti F, Rimkus S and Burlando P. 2009. Assessing the transferability and 567 robustness of an enhanced temperature-index glacier-melt model. Journal of Glaciology 55: 568 258-274. doi: 10.3189/002214309788608804. 
569 Carturan LF, Cazorzi G and Dalla Fontana. 2012. Distributed mass-balance modelling on two 570 neighbouring glaciers in Ortles-Cevedale, Italy, from 2004 to 2009. Journal of Glaciology 58: 467-486. doi: 10.3189/2012jog11j111.

572 Cazorzi F and Fontana GD. 1996. Snowmelt modelling by combining air temperature and a 573 distributed radiation index. Journal of Hydrology 181: 169-87. doi: 10.1016/0022574 1694(95)02913-3.

575 Daly SF, Davis R, Ochs E and Pangburn T. 2000. An approach to spatially distributed snow 576 modelling of the Sacramento and San Joaquin basins, California. Hydrological Processes 14: 3257-3271. doi: 10.1002/1099-1085(20001230)14:18<3257::AID-HYP199>3.0.CO;2-Z.

578 Dee DP, Uppala SM, Simmons AJ, Berrisford P, Poli PK, Kobayashi S, Andrae U, 579 Balmaseda MA, Bal samo G, Bauer P, Bechtold P, Beljaars ACM, Van de Berg L, Bidl ot J, 580 Bormann N, Delsol C, Dragani R, Fuentes M, Geer AJ, Haimberger L, Healy SB, Hersbach 581 H, Hólm EV, Isaksen L, Kållberg P, Köhler M, Matricardi M, Mc Nally AP, Monge-Sanz 582 BM, Morcrette J, Park B, Peubey C, DE Rosnay P, Tavolato C, Thépaut J. And Vitart F. 583 2011. The ERA-Interim reanalysis: configuration and performance of the data assimilation 584 system. Quarterly Journal of the Royal Meteorological Society 137: 553-597. doi: 10.1002/qj.828.

586 Dobler C, Hagemann S, Wilby RL and Stötter J. 2012. Quantifying different sources of 587 uncertainty in hydrological projections at the catchment scale. Hydrology and Earth Systems Science 16: 4343-4360. doi: 10.5194/hess-16-4343-2012.

589 Dyer A. 1974. A review of flux-profile relationships. Boundary-LayerMeteorology 7: 363590 372. doi: 10.1007/BF00240838.

591 Elsner JB and Schmertmann CP. 1994. Assessing Forecast Skill through Cross Validation. 592 Weather and Forecasting 9: 619-624. doi: 10.1175/1520593 0434(1994)009<0619:AFSTCV>2.0.CO;2.

594 Fealy R and Sweeney J. 2007. Identification of frequency changes in synoptic circulation 595 types and consequences for glacier mass balance in Norway. Norsk Geografisk Tidsskrift 61: 596 76-91. doi: 10.1080/00291950701374328. 
597 Fettweis X, Mabille G, Erpicum M, Nicolay S and Broeke M. 2011. The 1958-2009 598 Greenland ice sheet surface melt and the mid-tropospheric atmospheric circulation. Climate 599 Dynamics 36: 139-159. doi: 10.1007/s00382-010-0772-8.

600 Fettweis X, Hanna E, Lang C, Belleflamme A, Erpicum M and Gallée H. 2013. Brief 601 communication: Important role of the mid-tropospheric atmospheric circulation in the recent 602 surface melt increase over the Greenland ice sheet. The Cryosphere 7: 241-248. doi: $603 \quad 10.5194 / t c-7-241-2013$.

604 Grudd H and Schneider T. 1996. Air temperature at Tarfala research station 1946-1995. 605 Geografiska Annaler A 78: 115-120. doi: 10.2307/520973.

606 Guðmundsson S, Björnsson H, Pálsson F and Haraldsson HH. 2009. Comparison of energy 607 balance and degree-day models of summer ablation on the Langjökull ice cap, SW-Iceland. 608 Jökull 59: 1-17.

609 Hanna E, Jones JM, Cappelen J, Mernild SH, Wood L, Steffen K and Huybrechts P. 2012. 610 The influence of North Atlantic atmospheric and oceanic forcing effects on 1900-2010 611 Greenland summer climate and ice melt/runoff. International Journal of Climatology 33: 612 862-880. doi: 10.1002/joc.3475.

613 Hock R. 1999. A distributed temperature-index ice- and snowmelt model including potential 614 direct solar radiation. Journal of Glaciology 45: 101-11.

615 Hock R. 2003. Temperature index melt modelling in mountain areas. Journal of Hydrology 616 282: 104-115. doi: 10.1016/s0022-1694(03)00257-9.

617 Hock R. 2005. Glacier melt: a review of processes and their modeling. Progress in Physical 618 Geography 29: 362-391. doi: 10.1191/0309133305pp453ra.

619 Hock R and Holmgren B. 1996. Some aspects of energy balance and ablation of 620 Storglaciären, northern Sweden. Geografiska Annaler A 78:121-131. doi: 10.2307/520974.

621 Hock R and Holmgren B. 2005. A distributed surface energy balance model for complex 622 topography and its application to Storglaciären, Sweden. Journal of Glaciology 51: 25-36. 623 doi: 10.3189/172756505781829566. 
624 Hodgkins R, Carr S, Pálsson F, Guðmundsson S and Björnsson H. 2012. Sensitivity analysis 625 of temperature-index melt simulations to near-surface lapse rates and degree-day factors at 626 Vestari-Hagafellsjökull, Langjökull, Iceland. Hydrological Processes 26: 3736-3748. doi: 627 10.1002/hyp.8458.

628 Holland MM and Bitz CM. 2003. Polar amplification of climate change in coupled models. 629 Climate Dynamics 21: 221-232. doi: 10.1007/s00382-003-0332-6.

630 Irvine-Fynn TDL, Hanna E, Barrand NE, Porter PR, Kohler J and Hodson AJ. 2014. 631 Examination of a physically based, high-resolution, distributed Arctic temperature-index melt 632 model, on Midtre Lovénbreen, Svalbard. Hydrological Processes 28: 134-149. doi: $633 \quad$ 10.1002/hyp.9526.

634 Jonsell U, Hock R, and Duguay M. 2013. Recent air and ground temperature increases at 635 Tarfala Research Station, Sweden. Polar Research 32. doi: 10.3402/polar.v32i0.19807.

636 Kalkstein LS and Corrigan P. 1986. A synoptic climatological approach for geographical 637 analysis: Assessment of sulphur dioxide concentrations. Annals of the Association of 638 American Geographers 76: 381-395. doi: 10.1111/j.1467-8306.1986.tb00126.x.

639 Kalkstein LS, Dunne PC and Vose RS. 1990. Detection of climatic change in the western 640 North American Arctic using a synoptic climatological approach. Journal of Climate 3: 1153641 1167. doi: 10.1175/1520-0442(1990)003<1153:DOCCIT>2.0.CO;2.

642 Koblet T, Gärtner-Roer I, Zemp M, Jansson P, Thee P, Haeberli W and Holml und P. 2010. 643 Reanalysis of multi-temporal aerial images of Storglaciären, Sweden (1959-99)—Part 1: 644 Determination of length, area, and volume changes. The Cryosphere 4: 333-343. doi: 645 10.5194/tc-4-333-2010.

646 Konya K, Matsumoto T and Naruse R. 2004. Surface heat balance and spatially distributed 647 ablation modelling at Koryto Glacier, Kamchatka peninsula, Russia. Geografiska Annaler A 648 86: 337-348. doi: 10.1111/j.0435-3676.2004.00236.x.

649 Kuhn M. 1993. Methods of assessing the effects of climatic changes on snow and glacier 650 hydrology. IAHS Publication 218: 135-144. 
651 Lang $\mathrm{H}$ and Braun L. 1990. On the information content of air temperature in the context of snow melt estimation. IAHS Publication 190: 347-354.

653 Lall U and Sharma A. 1996. A nearest neighbor bootstrap for resampling hydrologic time 654 series. Water Resources Research 32: 679-693. doi: 10.1029/95WR02966.

655 Maraun D, Wetterhall F, Ireson AM, Chandler RE, Kendon EJ, Widmann M and Thiele-Eich 656 I. 2010. Precipitation downscaling under climate change: Recent developments to bridge the 657 gap between dynamical models and the end user. Reviews of Geophysics 48. doi: 658 10.1029/2009RG000314.

659 Marzeion B, Jarosch AH and Hofer M. 2012. Past and future sea-level change from the 660 surface mass balance of glaciers. The Cryosphere 6: 1295-1322. doi: 10.5194/tc-6-12956612012.

662 Matthews TKR. 2013. Glacier-climate interactions: a synoptic approach. PhD thesis 663 available at: https://dspace.lboro.ac.uk/2134/12558.

664 Meehl GA, Stocker TF, Collins WD, Friedlingstein P, Gaye AT, Gregory JM, Kitoh A, 665 Knutti R, Murphy JM, Noda A, Raper SCB, Watterson IG, Weaver, AJ and Zhao ZC. 2007. 666 Global Climate Projections. In: Climate Change 2007: The Physical Science Basis 667 Contribution of Working Group I to the Fourth Assessment Report of the Intergovernmental 668 Panel on Climate Change [Solomon S, Qin D, Manning M, Chen Z, Marquis M, Averyt KB, 669 Tignor $\mathrm{M}$ and Miller HL (eds.)]. Cambridge University Press, Cambridge, United Kingdom 670 and New York, NY, USA.

671 Müller F and Keeler CM. 1969. Errors in short-term ablation measurements on melting ice 672 surfaces. Journal of Glaciology 8: 91-105.

673 Munro DS. 1990. Comparison of melt energy computations and ablatometer measurements 674 on melting ice and snow. Arctic and Alpine Research 22: 153-162. doi: 10.2307/1551300.

675 Nash JE and Sutcliffe JV. 1970. River flow forecasting through conceptual models. Part 1. A 676 discussion of principles. Journal of Hydrology 10: 282-290. doi: 10.1016/0022677 1694(70)90255-6. 
679 Paulson CA. 1970. The mathematical representation of wind speed and temperature profiles 680 in the unstable atmospheric surface layer. Journal of Applied Meteorology 9: 857-861. doi: 681 10.1175/1520-0450(1970)009<0857:TMROWS>2.0.CO;2.

682 Pellicciotti F, Brock BW, Strasser U, Burlando P, Funk M and Corripio J. 2005. An enhanced 683 temperature-index glacier melt model including the shortwave radiation balance: 684 development and testing for Haut Glacier d' Arolla, Switzerland. Journal of Glaciology 51: 685 573-587. doi: 10.3189/172756505781829124.

686 Radić V and Hock R. 2011. Regionally differentiated contribution of mountain glaciers and 687 ice caps to future sea-level rise. Nature Geoscience 4: 91-94. doi: 10.1038/ngeo1052.

Raper SCB and Braithwaite RJ. 2006. Low sea level rise projections from mountain glaciers 689 and icecaps under global warming. Nature 439: 311-313. doi: 10.1038/nature04448.

Sedlar J and Hock R. 2009. Testing longwave radiation parameterizations under clear and 691 overcast skies at Storglaciären, Sweden. The Cryosphere 3: 75-84. doi: 10.5194/tc-3-75692 2009.

693 Serreze M, Barrett A, Stroeve J, Kindig D and Holland M. 2009. The emergence of surface694 based Arctic amplification. The Cryosphere 3: 11-19. doi: 10.5194/tc-3-11-2009.

695 Sheridan SC. 2002. The redevelopment of a weather-type classification scheme for North 696 America. International Journal of Climatology 22: 51-68. doi: 10.1002/joc.709.

697 Van den Dool HM. 1994. Searching for analogues, how long must we wait? Tellus A 46: 314698 324. doi: 10.1034/j.1600-0870.1994.t01-2-00006.x.

699 Wilby RL. 1997. Nonstationarity in daily precipitation series: implications for GCM 700 downscaling using atmospheric circulation indices. International Journal of Climatology 17: 701 439-454. doi: 10.1002/(SICI)1097-0088(19970330)17:4<439::AID-JOC145>3.0.CO;2-U.

702 Willis IC. Arnold NS and Brock BW. 2002. Effect of snowpack removal on energy balance, 703 melt and runoff in a small supraglacial catchment. Hydrological Processes 16: 2721-2749. 704 doi: 10.1002/hyp.1067. 
705 Willmott CJ, Ackleson SG, Davis RE, Feddema JJ, Klink KM, Legates DR and Rowe CM. 706 1985. Statistics for the evaluation and comparison of models. Journal of Geophysical 707 Research: Oceans (1978-2012) 90: 8995-9005. doi: 10.1029/JC090iC05p08995.

708 Young KC. 1994. A multivariate chain model for simulating climatic parameters from daily 709 data. Journal of Applied Meteorology 33: 661-671. doi: 10.1175/1520 $710 \quad$ 0450(1994)033<0661:AMCMFS>2.0.CO;2.

711 Zhang S, Ye B, Liu S, Zhang X and Hagemann S. 2012. A modified monthly degree-day 712 model for evaluating glacier runoff changes in China. Part I: model development. 713 Hydrological Processes 26: 1686-1696. doi: 10.1002/hyp.82.

714

715

716

717

718

719

720

721

722

723

724

725

726

727

728

729

730

731

732

733

734

735 
Table 1. Details of the sensors deployed at the glacier automatic weather stations, whose locations are indicated in Figure 1.

Table 2. Details of the data series used to force the SEB model on Storglaciären for different time periods. The 'adjusted TRS' meteorological series relates to those variables that are observed at the Tarfala Research Station, and adjusted to the location of the glacier AWS using empirical functions. See the text in Section 2.1 for further information.

Table 3. Agreement between the parameterized meteorological variables for the location of the glacier AWS on Storglaciären (determined through empirical adjustment of observations made at TRS), and the meteorology measured on the glacier. Agreement is presented in terms of the Nash-Sutcliffe Efficiency Coefficient (Eq. 4). $R^{2}$ is calculated for hourly and daily means (left- and right-hand columns, respectively), for the period when glacier observations are available (Table 2).

Table 4. Details of the SEB computations used to determine the reference melt series at each location. Further information regarding the choice of model structure and parameter values can be found in Matthews (2013) and in Section 2.1.

Table 5. Mean meteorology and SEB components for the locations of the AWSs ( \pm standard deviation). Note that for Storglaciären, these results reflect meteorological data recorded in situ, and TRS data adjusted to the glacier location (see Table 2 for the associated time periods). ${ }^{1}$ Cloud cover is defined as the mean ratio of received to potential, clear-sky global radiation. ${ }^{2}$ Thermal emissivity is defined as the mean ratio of received incident longwave radiation to that emitted by a blackbody radiator at the two-metre air temperature.

Table 6. Performance measures for the temperature-index models. The $S$ series (modelled with coefficients which are static) and the $W T$ series (modelled with coefficients which are conditioned on synoptic weather types) are compared to the reference melt rates (generated with the SEB models) at hourly and daily resolution (left- and right-hand-side columns, respectively). $\Delta R^{2}$ gives the difference in Nash-Sutcliffe Efficiency Coefficient (as indicated in brackets), and $R^{2}(S)$ gives this improvement as a \% of the $R^{2}$ for the $S$ series. $p$ gives the empirically-determined probability of not obtaining an improvement in annual melt simulation using the weather-type calibration routine.

Table 7. Mean coefficient values $(\mu)$ and their coefficients of variation $\left(c_{v}=\sigma / \mu * 100\right)$ for the temperatureindex models used to simulate the $S$ and $W T$ series. The units for the coefficients are as follows: $M F_{\text {snow/ice }}=$ mm w.e. ${ }^{\circ} \mathrm{C}^{-1} \mathrm{~h}^{-1} ; T M F=\mathrm{mm}$ w.e. ${ }^{\circ} \mathrm{C}^{-1} \mathrm{~h}^{-1} ; R T M F=\mathrm{mm}$ w.e. $\mathrm{W}^{-1} \mathrm{~m}^{2}{ }^{\circ} \mathrm{C}^{-1} \mathrm{~h}^{-1}$; and $R M F=\mathrm{mm}$ w.e. $\mathrm{W}^{-1} \mathrm{~m}^{2} \mathrm{~h}^{-1}$.

Table 8. The relative skill of the temperature-index models with static and weather-type-dependent coefficients, but for Storglaciären only. Refer to Table 6 and the text in Section 5.2 for further information. 
776 Figure Captions.

777 Figure 1. Location of study sites. Vestari Hagafellsjökull is an outlet of the Langjökull Ice Cap: the outline of the entire ice cap is shown on the left-hand-side of the figure. Note that both the glacier AWS on Storglaciären (GAWS) and the AWS at the Tarfala Research Station (TRS) are shown on the right-hand-side of the figure. Only the scale varies between the left and right sides of the figure (shown by the separate scale bars); both maps share the same legend.

Figure 2. Comparisons of cumulative ablation simulated by the SEB models and estimated from proxy measurements of surface lowering converted to water equivalent (see Section 2.1). Cumulative uncertainty in simulated ablation (given by the blue patch) is estimated from the sensor uncertainties following the method outlined in Greuell and Smeets (2001). Note that periods when accumulation was observed are removed from the comparison at Vestari Hagafellsjökull, which accounts for the uneven length of annual series at VH 1100.

Figure 3. Comparisons of melt simulated by the SEB model at Storglaciären when forced with meteorological variables recorded on-glacier, and when forced with the adjusted TRS meteorological series (GAWS and TRS melt, respectively). $R^{2}$ is defined in Eq. 4.

Figure 4. Daily albedo observed at the glacier AWSs. Red indicates ice at VH 500 and Storglaciären, and firn at V 1100; blue illustrates periods of snow cover for all locations. These surface types were identified using albedo thresholds of 0.38, 0.15, and 0.5 at Storglaciären, VH 500, and VH 1100, respectively. The thresholds were prescribed after manual examination of the albedo record at each location (see Matthews (2013) for further information). The vertical grey lines separate successive periods of observation (June-August on Vestari Hagafellsjökull, and July-August on Storglaciären). The stability of albedo at Storglaciären prior to 2010 reflects the fact that albedo was not measured on the glacier prior to this year, so it was instead prescribed (Section 2.1).

Figure 5. Comparisons between reference melt series, and the melt simulated by the temperature-index models

803 at hourly resolution. The locations are separated by columns, and model variants are differentiated by row. Note 804 that rows are labelled such that the first letter corresponds to the model name, and the subscript indicates 805 whether static (S) or weather-type-dependent (WT) model coefficients were applied in the model being 806 evaluated. The bracketed term in the y-axis labels denotes whether the ETI models were forced with observed, 807 or potential, clear-sky global radiation (see Section 2.3). The relative density of points in the plots is indicated 808 by shading (red = high density; blue = low density).

810 Figure 6. Comparisons between reference melt series, and the melt simulated by the temperature-index models 811 at daily resolution. See the caption of Figure 5 for further information.

813 Figure 7. The $R^{2}$ achieved by the unmodified temperature-index models in the cross-validation procedure (i.e. 814 those models with static model coefficients) versus the improvement in $R^{2}$ ( $R^{2}$ for the $W T$ series minus $R^{2}$ for the 
$815 S$ series) attained when coefficients are calibrated with respect to weather types. The ellipse bounds the results

816 from Model A when evaluated at hourly resolution: $r_{1}$ and $r_{2}$ give the Pearson product-moment correlations

817 between the series when these points are included, and omitted from the correlation analysis, respectively: both

$818 \quad r$-values are significant at $p<0.05$.

819

820 Figure 8. An example of the results from the bootstrap simulation described in Section 2.4, which assesses the

821 significance of the improvement in temperature-index model performance when coefficients are varied as a

822 function of weather type. Displayed are the results of evaluating Model A at daily resolution. The circles and

823 bars above the probability density functions denote the means and standard deviations, respectively.

824

825 Figure 9. The response surface for the ETI model coefficients is given by the contour field. This was generated 826 by simultaneously varying coefficients over a wide range and calculating $R^{2}$ for each resulting combination 827 performed using all available data to train the models and evaluate their performance (i.e. off-line from the 828 cross-validation procedure). The black and magenta scatter plots indicate the calibrated coefficient values 829 obtained from the cross-validation procedure for the models with weather-type-dependent and static model 830 coefficients, respectively. Note that the y-axis represents either the $R T M F$ or $R M F$ coefficient, depending on the model (models C and B, respectively)

832

833 Figure 10. Pearson product-moment correlation coefficients $(r)$ between the value of the temperature-index 834 model coefficients calibrated for each of the weather types during the cross-validation procedure, and the mean 835 daily meteorological/energy balance conditions at the location of the glacier AWSs for the day that the 836 coefficients were calibrated for. Note that the dotted lines indicate the respective critical values of $r$ to reject the 837 null hypothesis that $r=0$ according to the $t$-test. The different colours of these lines correspond to the different 838 sample sizes for snow and ice surfaces relevant for Model A, which are colour-coded to match the relevant 839 legend entries for this model. Critical $r$ values irrespective of surface type (and hence a for larger sample size) 840 are plotted, but are obscured by the lower magnitude critical values plotted for the snow/ice surfaces.

841

842 Figure 11. Correlations for model coefficients calibrated at different elevations on Vestari Hagafellsjökull 843 between weather types. All correlations are significant at $p<0.05$ according to a two-tailed $t$-test, except the correlation observed for $M F_{\text {snow }}$, which has a $p$-value of 0.08 .

845

846

847

848

849

850

851

852 


\begin{tabular}{|c|c|c|c|}
\hline Measurement (height) & Sensor & Accuracy ( \pm ) & $\begin{array}{l}\text { Period that data } \\
\text { used relates to } \\
\text { (Julian day, year) }\end{array}$ \\
\hline \multicolumn{4}{|c|}{ Vestari Hagafellsjökull } \\
\hline Air temperature (2 m) & Vaisala HMP35 & $0.2^{\circ} \mathrm{C}$ & \multirow{5}{*}{$\begin{array}{l}\text { VH 500: 152-243, } \\
\text { 2001-2007 } \\
\text { VH 100: 152-243; } \\
\text { 2001-2009 }\end{array}$} \\
\hline Relative humidity (2 m) & Vaisala HMP35 & $2 \%$ & \\
\hline Wind speed (2 m) & R.M. Young 05103 & $0.3 \mathrm{~m} \mathrm{~s}^{-1}$ & \\
\hline Shortwave radiation (2 m) & $\begin{array}{l}\text { Kipp and Zonen CNR1- } \\
\text { CM3 }\end{array}$ & $3 \%$ & \\
\hline Longwave radiation (2 m) & $\begin{array}{l}\text { Kipp and Zonen CNR1- } \\
\text { CG3 }\end{array}$ & $3 \%$ & \\
\hline Ablation (variable) & Cambell Scientific SR50 & $\operatorname{Max}(0.01 \mathrm{~m}, 0.4 \%)$ & $\begin{array}{l}\text { VH 500: 152-243, } \\
\text { 2001-2005; 191-243, } \\
\text { 2006; 152-243, 2007 } \\
\text { VH 1100: 152-243, } \\
\text { 2001-2007; 152-235, } \\
\text { 2008; 152-243, 2009 }\end{array}$ \\
\hline \multicolumn{4}{|c|}{ Storglaciären } \\
\hline Air temperature (2 m) & Vaisala HMP45C & $0.3^{\circ} \mathrm{C}$ at $0^{\circ} \mathrm{C}$ & $\begin{array}{l}\text { 192-243, 2010; 191- } \\
\text { 243, } 2011\end{array}$ \\
\hline Relative humidity (2 m) & Vaisala HMP45C & $\begin{array}{l}2 \%(0-90 \%) ; 3 \%(90- \\
100 \%)\end{array}$ & $\begin{array}{l}\text { 192-243, 2010; 191- } \\
\text { 243, } 2011\end{array}$ \\
\hline Wind speed/direction (2 m) & Young 05103 & $0.3 \mathrm{~m} \mathrm{~s}^{-1}$ & $\begin{array}{l}\text { 192-243, 2010; 191- } \\
\text { 243, } 2011\end{array}$ \\
\hline \multirow{2}{*}{ Shortwave radiation $(1.5 \mathrm{~m})$} & $\begin{array}{l}\text { Kipp and Zonen } \\
\text { CM7B }\end{array}$ & $8 \%$ & 192-243, 2010 \\
\hline & $\begin{array}{l}\text { Kipp and Zonen CNR1, } \\
\text { CM3 }\end{array}$ & $3 \%$ & 191-243, 2011 \\
\hline Longwave radiation (1.5 m) & $\begin{array}{l}\text { Kipp and Zonen CNR1, } \\
\text { CG3 }\end{array}$ & $3 \%$ & 191-243, 2011 \\
\hline \multirow[b]{2}{*}{ Ablation (variable/NA) } & Campbell Scientific SR50 & $\operatorname{Max}(0.01 \mathrm{~m}, 0.4 \%)$ & 196-243, 2011 \\
\hline & $\begin{array}{l}\text { Manual stake } \\
\text { measurements }\end{array}$ & Estimated: 5 mm & 192-243, 2011 \\
\hline
\end{tabular}


Table 2

\begin{tabular}{|l|c|}
\hline \multicolumn{1}{|c|}{ Data used for SEB simulation } & Period (hour, Julian day, year) \\
\hline $\begin{array}{l}\text { Adjusted TRS meteorological series (all variables) } \\
\text { expressions of Sedlar and Hock (2009); all other } \\
\text { meteorological variables taken directly from } \\
\text { observations at glacier AWS }\end{array}$ & $01: 00,182,2011-13: 00,191,2011$ \\
\hline $\begin{array}{l}\text { Incident longwave radiation parameterized using the } \\
\text { Observations at glacier AWS (all variables) }\end{array}$ & $15: 00,192,2010-24: 00,243,2010$ \\
\hline
\end{tabular}

858

859

860

861

862

863

864

865

866

867

868

869

870

871

872

873

874

875

876

877

878 
879

880

881

Table 3

\begin{tabular}{lcc}
\hline & $\boldsymbol{R}^{\mathbf{2}}$ (hourly) & $\boldsymbol{R}^{\mathbf{2}}$ (daily) \\
\hline Air temperature & 0.873 & 0.946 \\
Vapour Pressure & 0.855 & 0.938 \\
Wind Speed & 0.416 & 0.670 \\
Shortwave radiation & 0.746 & 0.881 \\
Longwave radiation & 0.493 & 0.794 \\
\hline
\end{tabular}

882

883

884

885

886

887

888

889

890

891

892

893

894

895

896

897

898

899

900

901

902

903

904

905

906

907 


\begin{tabular}{|c|c|c|c|c|}
\hline \multicolumn{5}{|c|}{$\begin{array}{l}\text { Model for calculating the SEB }(Q): Q=Q_{H}+Q_{L}+Q_{S W}+Q_{L W} \\
\text { Time-step is one hour }\end{array}$} \\
\hline $\begin{array}{l}\text { SEB } \\
\text { component }\end{array}$ & $\begin{array}{c}\text { Procedure } \\
\text { for } \\
\text { calculation }\end{array}$ & $\begin{array}{l}\text { Associated } \\
\text { parameters }\end{array}$ & Vestari Hagafellsjökull & Storglaciären \\
\hline \multirow{4}{*}{$\begin{array}{l}\text { Turbulent } \\
\text { heat flux } \\
\text { (sensible: } \\
Q_{H} \text { and } \\
\text { latent: } Q_{L} \text { ) }\end{array}$} & \multirow{4}{*}{$\begin{array}{l}\text { Bulk } \\
\text { aerodynamic } \\
\text { method }\end{array}$} & $\begin{array}{l}\text { Roughness } \\
\text { length of } \\
\text { momentum }\end{array}$ & $\begin{array}{l}\text { Ice: } 10 \mathrm{~mm} \\
\text { Firn: } 2 \mathrm{~mm} \\
\text { Snow: } 0.1 \mathrm{~mm}\end{array}$ & $\begin{array}{l}\text { Ice: } 2.7 \mathrm{~mm} \\
\text { Snow: } 0.15 \mathrm{~mm}\end{array}$ \\
\hline & & $\begin{array}{l}\text { Roughness } \\
\text { lengths of } \\
\text { water } \\
\text { vapour and } \\
\text { temperature }\end{array}$ & $\begin{array}{l}\text { Modelled according to } \\
\text { Andreas (1987). }\end{array}$ & $\begin{array}{l}\text { Modelled according to Andreas } \\
\text { (1987) }\end{array}$ \\
\hline & & $\begin{array}{l}\text { Stability } \\
\text { corrections } \\
\text { for } \\
\text { turbulent } \\
\text { heat flux } \\
\text { calculations }\end{array}$ & $\begin{array}{l}\text { Non-linear expressions of } \\
\text { Beljaars and Holtslag (1991) } \\
\text { used for stable conditions } \\
\text { (glacier surface temperature } \\
\text { below air temperature); } \\
\text { equations of Paulson (1970) } \\
\text { and Dyer (1974) applied for } \\
\text { unstable case. }\end{array}$ & Neutral stratification assumed \\
\hline & & $\begin{array}{l}\text { Glacier } \\
\text { surface } \\
\text { temperature }\end{array}$ & $\begin{array}{l}\text { Assumed to be at the melting } \\
\text { point }\left(0^{\circ} \mathrm{C}\right) \text {. }\end{array}$ & $\begin{array}{l}\text { Assumed to be at the melting } \\
\text { point when the longwave } \\
\text { radiation balance is measured at } \\
\text { the glacier AWS; zero-degree } \\
\text { assumption also assumed when } \\
\text { parameterized TRS data used to } \\
\text { drive the SEB models, unless } \\
\text { negative } Q \text { is encountered: in this } \\
\text { case, the surface temperature is } \\
\text { lowered iteratively }\left(-0.25^{\circ} \mathrm{C} \text { steps) }\right. \\
\text { until } Q=0\end{array}$ \\
\hline $\begin{array}{l}\text { Net } \\
\text { shortwave } \\
\text { heat flux } \\
\left(Q_{S W}\right)\end{array}$ & $\begin{array}{l}\text { Incident flux } \\
\text { minus } \\
\text { reflected } \\
\text { flux }\end{array}$ & Albedo & $\begin{array}{l}N A \text { (radiation balance } \\
\text { measured directly at AWS) }\end{array}$ & $\begin{array}{l}\text { Direct observations used when } \\
\text { available. Otherwise (when the } \\
\text { parameterized TRS data are used } \\
\text { to force the SEB model), albedo is } \\
\text { prescribed as the mean ice albedo } \\
\text { observed during the period of } \\
\text { glacier AWS operation }\end{array}$ \\
\hline $\begin{array}{l}\text { Net } \\
\text { longwave } \\
\text { heat flux } \\
\left(Q_{L W}\right)\end{array}$ & $\begin{array}{l}\text { Incident flux } \\
\text { minus the } \\
\text { flux emitted } \\
\text { by the } \\
\text { glacier } \\
\text { surface }\end{array}$ & $\begin{array}{l}\text { Emitted } \\
\text { longwave } \\
\text { radiation }\end{array}$ & $\begin{array}{l}\text { NA (radiation balance } \\
\text { measured directly at AWS) }\end{array}$ & $\begin{array}{l}\text { Direct observations used when } \\
\text { available. Otherwise (when the } \\
\text { parameterized TRS data are used } \\
\text { to force the SEB model), } \\
\text { calculated from the glacier } \\
\text { surface temperature using the } \\
\text { Stefan Boltzmann law and } \\
\text { assuming unit emissivity }\end{array}$ \\
\hline
\end{tabular}


Table 5

\begin{tabular}{|c|c|c|c|}
\hline & $\begin{array}{c}\text { VH } 1100 \\
( \pm \sigma)\end{array}$ & $\begin{array}{c}\text { VH } 500 \\
( \pm \sigma)\end{array}$ & $\begin{array}{c}\text { Storglaciären } \\
( \pm \sigma)\end{array}$ \\
\hline Period & Jun-Aug, 2001-2009 & Jun-Aug, 2001-2007 & Jul-Aug, 2005-2011 \\
\hline Air Temperature $\left({ }^{\circ} \mathrm{C}\right)$ & $2.0(1.4)$ & $5.3(1.3)$ & $5.1(2.5)$ \\
\hline Wind Speed $\left(\mathrm{m} \mathrm{s}^{-1}\right)$ & $5.4(2.8)$ & $5.3(1.8)$ & $2.9(1.3)$ \\
\hline Mixing Ratio ( $\mathrm{g} \mathrm{kg}^{-1}$ ) & $4.7(0.5)$ & $5.0(0.6)$ & $4.6(1.7)$ \\
\hline Incident Shortwave Radiation $\left(\mathrm{W} \mathrm{m}{ }^{-2}\right)$ & $200(86.3)$ & $163(92.9)$ & $158(81.8)$ \\
\hline Reflected Shortwave Radiation $\left(\mathrm{W} \mathrm{m} \mathrm{m}^{-2}\right)$ & $104(61.0)$ & $12.6(24.3)$ & $62.1(32.8)$ \\
\hline Albedo (dimensionless) & $0.60(0.13)$ & $0.10(0.10)$ & $0.40(0.10)$ \\
\hline Cloud Cover (fraction) $)^{1}$ & $0.48(0.18)$ & $0.58(0.21)$ & $0.60(0.19)$ \\
\hline Incident Longwave Radiation( $\left.\mathrm{W} \mathrm{m}^{-2}\right)$ & $311(30.9)$ & $316(28.0)$ & $302(24.5)$ \\
\hline Emitted Longwave Radiation( $\left.\mathrm{W} \mathrm{m}^{-2}\right)$ & $311(4.8)$ & $315(1.5)$ & $314(4.2)$ \\
\hline Emissivity (fraction) $^{2}$ & $0.81(0.09)$ & $0.92(0.08)$ & $0.89(0.07)$ \\
\hline Sensible Heat Flux $\left(\mathrm{W} \mathrm{m}^{-2}\right)$ & $20.2(21.9)$ & $70.0(29.5)$ & $38.6(19.0)$ \\
\hline Latent Heat Flux $\left(\mathrm{W} \mathrm{m}^{-2}\right)$ & $6.6(16.4)$ & $28.1(22.2)$ & $13.3(16.6)$ \\
\hline RMSE (mm w.e. $\left.\mathrm{d}^{-1}\right)^{3}$ & 10.8 & 13.9 & 11.4 \\
\hline
\end{tabular}

913

914

915

916

917

918

919

920

921

922

923

924

925

926

927

928

929

930 
931

Table 6

\begin{tabular}{|c|c|c|c|c|c|c|c|c|c|c|c|}
\hline & & & Hou & & & & & & Daily & & \\
\hline & & & & & $\Delta R^{2}$ as & & & & $\Delta B^{2}$ & $\Delta R^{2}$ as & \\
\hline & inouer & $S$ & $W T$ & $(W T-S)$ & $\begin{array}{l}\% \text { oI } \\
R^{2}(S)\end{array}$ & $p(\%)$ & $S$ & $W T$ & $(W T-S)$ & $\begin{array}{l}\% \text { of } \\
R^{2}(S)\end{array}$ & $p(\%)$ \\
\hline & $\mathrm{A}$ & 0.330 & 0.354 & 0.024 & 7.3 & 0.6 & 0.635 & 0.729 & 0.094 & 14.8 & 1.9 \\
\hline 䒕: & $\mathrm{B}\left(I_{o}\right)$ & 0.819 & 0.871 & 0.052 & 6.3 & 0.0 & 0.652 & 0.796 & 0.145 & 22.2 & 0.1 \\
\hline •ฮี & $\mathrm{B}\left(I_{p}\right)$ & 0.725 & 0.799 & 0.074 & 10.2 & 0.0 & 0.739 & 0.806 & 0.068 & 9.2 & 1.2 \\
\hline कृ & $\mathrm{C}\left(I_{o}\right)$ & 0.893 & 0.924 & 0.031 & 3.5 & 0.0 & 0.752 & 0.868 & 0.116 & 15.4 & 0.0 \\
\hline क & $\mathrm{C}\left(I_{p}\right)$ & 0.719 & 0.790 & 0.071 & 9.9 & 0.0 & 0.731 & 0.809 & 0.077 & 10.6 & 0.3 \\
\hline & $\mathrm{A}$ & 0.072 & 0.105 & 0.034 & 47.3 & 0.2 & 0.106 & 0.377 & 0.271 & 255.4 & 0.1 \\
\hline 8 & $\mathrm{~B}\left(I_{o}\right)$ & 0.831 & 0.867 & 0.037 & 4.4 & 0.0 & 0.618 & 0.728 & 0.111 & 18.0 & 0.3 \\
\hline 웅 & $\mathrm{B}\left(I_{p}\right)$ & 0.538 & 0.693 & 0.155 & 28.9 & 0.0 & 0.130 & 0.486 & 0.356 & 274.9 & 0.0 \\
\hline 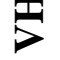 & $\mathrm{C}\left(I_{o}\right)$ & 0.916 & 0.944 & 0.029 & 3.1 & 0.0 & 0.702 & 0.867 & 0.166 & 23.6 & 0.0 \\
\hline & $\mathrm{C}\left(I_{p}\right)$ & 0.651 & 0.773 & 0.122 & 18.8 & 0.0 & 0.321 & 0.643 & 0.322 & 100.5 & 0.0 \\
\hline & A & 0.222 & 0.287 & 0.065 & 29.5 & 1.1 & 0.027 & 0.353 & 0.326 & 1207.0 & 1.58 \\
\hline 8 & $\mathrm{~B}\left(I_{o}\right)$ & 0.662 & 0.729 & 0.067 & 10.1 & 0.1 & 0.224 & 0.460 & 0.237 & 105.8 & 0.44 \\
\hline$\vec{Z}$ & $\mathrm{~B}\left(I_{p}\right)$ & 0.654 & 0.701 & 0.047 & 7.2 & 0.5 & 0.388 & 0.504 & 0.116 & 29.9 & 0.43 \\
\hline$\sum$ & $\mathrm{C}\left(I_{o}\right)$ & 0.860 & 0.902 & 0.043 & 5.0 & 0.0 & 0.638 & 0.806 & 0.168 & 26.4 & 0.01 \\
\hline & $\mathrm{C}\left(I_{p}\right)$ & 0.807 & 0.845 & 0.038 & 4.7 & 0.0 & 0.780 & 0.843 & 0.064 & 8.2 & 0.09 \\
\hline & Median & 0.719 & 0.790 & 0.047 & 7.3 & 0.0 & 0.633 & 0.728 & 0.145 & 23.6 & 0.1 \\
\hline
\end{tabular}

933

934

935

936

937

938

939

940

941

942

943

944

945

946

947

948 
Table 7

\begin{tabular}{|c|c|c|c|c|c|c|}
\hline \multirow[b]{2}{*}{ Coefficient } & \multicolumn{2}{|c|}{ Storglaciären } & \multicolumn{2}{|c|}{ VH 500} & \multicolumn{2}{|c|}{ VH 1100} \\
\hline & $\mu$ & $c_{v}$ & $\mu$ & $c_{v}$ & $\mu$ & $\mathrm{C}_{\mathrm{v}}$ \\
\hline \multicolumn{7}{|c|}{$S$ Series } \\
\hline$M F_{\text {snow }}(\mathrm{A})$ & 0.285 & 1.2 & 0.450 & 2.5 & 0.493 & 1.2 \\
\hline$M F_{\text {ice }}(\mathrm{A})$ & 0.290 & 3.6 & 0.523 & 1.0 & 0.593 & 3.0 \\
\hline$T M F\left(\mathrm{~B}_{0}\right)$ & 0.135 & 2.7 & 0.214 & 1.6 & 0.195 & 1.7 \\
\hline$T M F\left(\mathrm{~B}_{\mathrm{p}}\right)$ & 0.124 & 3.3 & 0.231 & 1.4 & 0.179 & 2.0 \\
\hline$T M F\left(\mathrm{C}_{0}\right)$ & 0.132 & 2.8 & 0.228 & 1.1 & 0.171 & 1.8 \\
\hline$T M F\left(\mathrm{C}_{\mathrm{p}}\right)$ & 0.143 & 2.0 & 0.225 & 2.1 & 0.182 & 1.4 \\
\hline$R T M F\left(\mathrm{~B}_{0}\right)$ & 0.0012 & 0.8 & 0.0019 & 1.2 & 0.0026 & 1.1 \\
\hline$R T M F\left(\mathrm{~B}_{\mathrm{p}}\right)$ & 0.0010 & 2.7 & 0.0012 & 2.4 & 0.0027 & 1.4 \\
\hline$R M F\left(\mathrm{C}_{0}\right)$ & 0.0087 & 0.8 & 0.0101 & 0.3 & 0.0089 & 0.5 \\
\hline$R M F\left(\mathrm{C}_{\mathrm{p}}\right)$ & 0.0065 & 2.3 & 0.0071 & 1.5 & 0.0083 & 0.7 \\
\hline \multicolumn{7}{|c|}{ WT Series } \\
\hline$M F_{\text {snow }}(\mathrm{A})$ & 0.317 & 23.8 & 0.448 & 5.1 & 0.549 & 17.3 \\
\hline$M F_{\text {ice }}(\mathrm{A})$ & 0.300 & 19.0 & 0.530 & 15.5 & 0.685 & 21.8 \\
\hline$T M F\left(\mathrm{~B}_{0}\right)$ & 0.115 & 32.6 & 0.183 & 39.7 & 0.167 & 72.8 \\
\hline$T M F\left(\mathrm{~B}_{\mathrm{p}}\right)$ & 0.113 & 32.5 & 0.209 & 27.0 & 0.160 & 57.7 \\
\hline$T M F\left(\mathrm{C}_{0}\right)$ & 0.107 & 36.8 & 0.193 & 34.0 & 0.130 & 71.3 \\
\hline$T M F\left(\mathrm{C}_{\mathrm{p}}\right)$ & 0.133 & 23.1 & 0.208 & 26.7 & 0.159 & 50.0 \\
\hline$R T M F\left(\mathrm{~B}_{0}\right)$ & 0.0014 & 25.5 & 0.0020 & 15.9 & 0.0031 & 23.0 \\
\hline$R T M F\left(\mathrm{~B}_{\mathrm{p}}\right)$ & 0.0012 & 41.3 & 0.0013 & 41.9 & 0.0031 & 27.9 \\
\hline$R M F\left(\mathrm{C}_{0}\right)$ & 0.0092 & 6.9 & 0.0105 & 3.9 & 0.0093 & 6.7 \\
\hline$R M F\left(\mathrm{C}_{\mathrm{p}}\right)$ & 0.0065 & 34.4 & 0.0073 & 33.4 & 0.0084 & 20.0 \\
\hline
\end{tabular}

951

952

953

954

955

956

957

958

959

960

961 
962

963

964

Table 8

\begin{tabular}{|c|c|c|c|c|c|c|}
\hline \multirow[b]{3}{*}{ Model } & \multicolumn{3}{|c|}{$2005-2010$} & \multicolumn{3}{|c|}{2011} \\
\hline & \multicolumn{2}{|c|}{$\overline{R^{2}}$} & \multicolumn{4}{|c|}{$\overline{R^{2}}$} \\
\hline & $W T$ & $S$ & $\Delta R^{2}(W T-S)$ & $W T$ & $S$ & $\Delta R^{2}(W T-S)$ \\
\hline \multicolumn{7}{|c|}{ Hourly } \\
\hline A & 0.333 & 0.356 & 0.023 & 0.299 & 0.335 & 0.037 \\
\hline B $\left(I_{o}\right)$ & 0.815 & 0.870 & 0.055 & 0.822 & 0.851 & 0.030 \\
\hline $\mathrm{B}\left(I_{p}\right)$ & 0.726 & 0.798 & 0.073 & 0.685 & 0.773 & 0.088 \\
\hline $\mathrm{C}\left(I_{o}\right)$ & 0.891 & 0.921 & 0.031 & 0.888 & 0.923 & 0.035 \\
\hline $\mathrm{C}\left(I_{p}\right)$ & 0.722 & 0.789 & 0.067 & 0.675 & 0.776 & 0.100 \\
\hline Mean & 0.697 & 0.747 & 0.050 & 0.674 & 0.732 & 0.058 \\
\hline \multicolumn{7}{|c|}{ Daily } \\
\hline A & 0.522 & 0.624 & 0.102 & 0.630 & 0.783 & 0.153 \\
\hline B $\left(I_{o}\right)$ & 0.519 & 0.739 & 0.220 & 0.809 & 0.848 & 0.039 \\
\hline $\mathrm{B}\left(I_{p}\right)$ & 0.670 & 0.766 & 0.096 & 0.800 & 0.843 & 0.043 \\
\hline $\mathrm{C}\left(I_{o}\right)$ & 0.700 & 0.842 & 0.143 & 0.822 & 0.913 & 0.091 \\
\hline $\mathrm{C}\left(I_{p}\right)$ & 0.707 & 0.782 & 0.076 & 0.715 & 0.830 & 0.115 \\
\hline Mean & 0.623 & 0.751 & 0.127 & 0.755 & 0.843 & 0.088 \\
\hline
\end{tabular}

965

966

967

968

969

970

971

972 
973

974

975

976

977
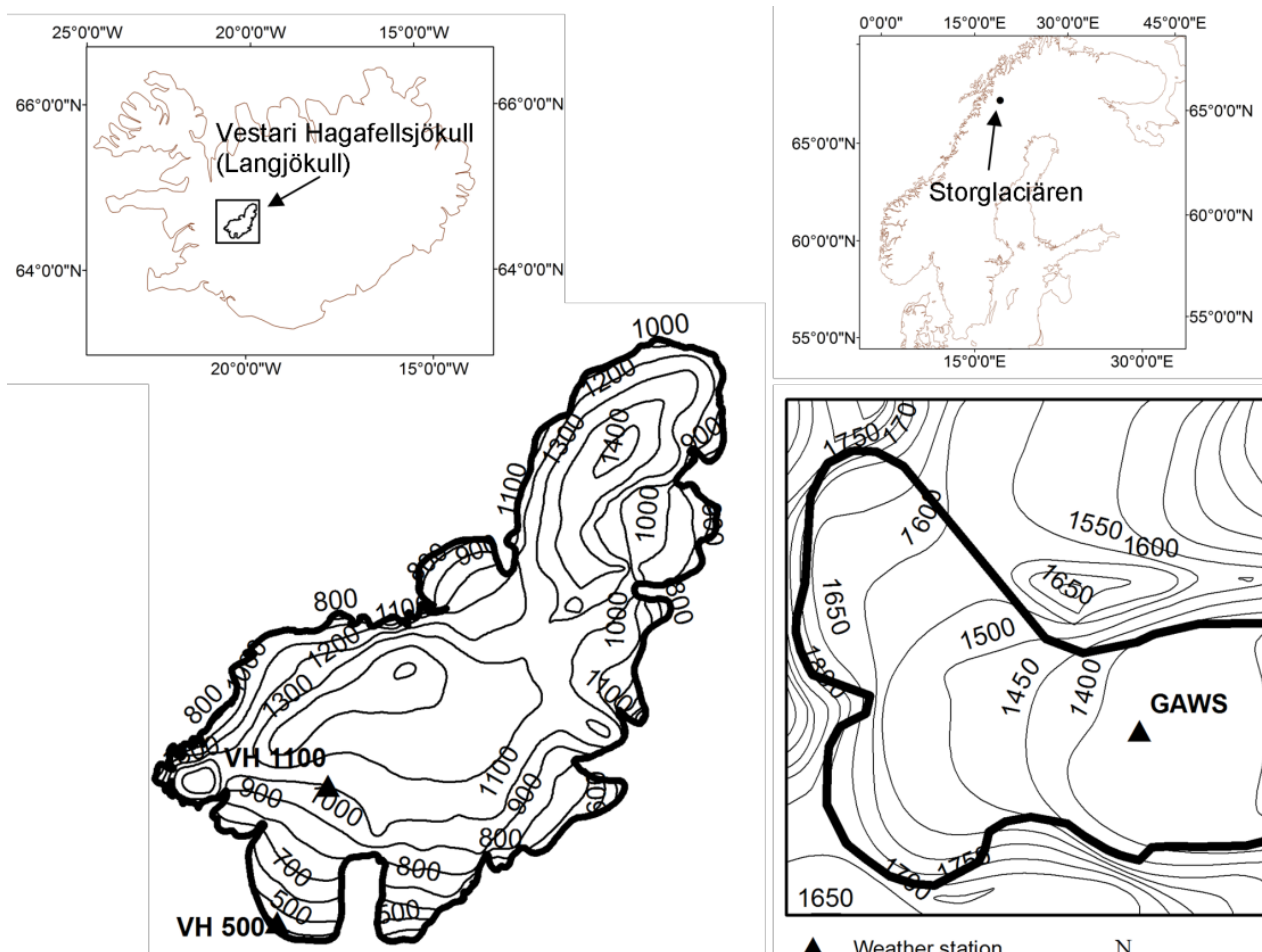

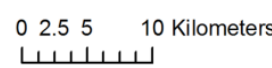

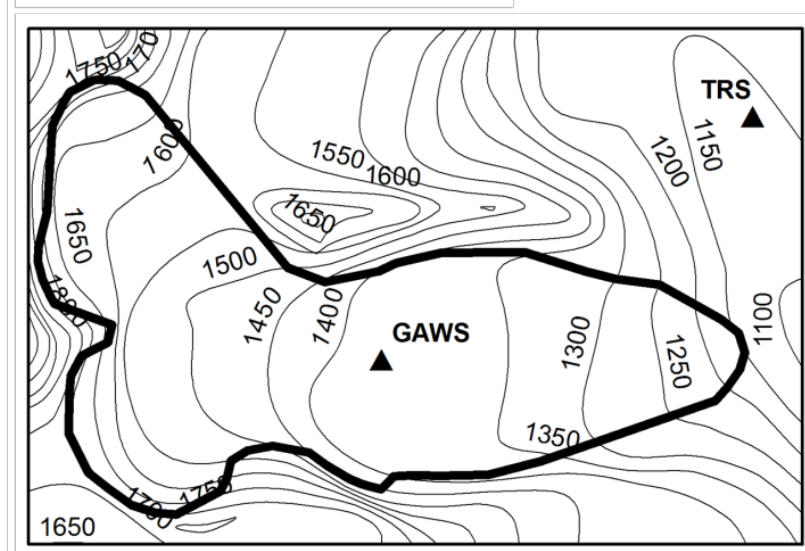

A Weather station

N $\begin{array}{llll}0 & 0.25 & 0.5 \\ & + & 1 & 1\end{array}$ 1 Kilometers

Figure 1 

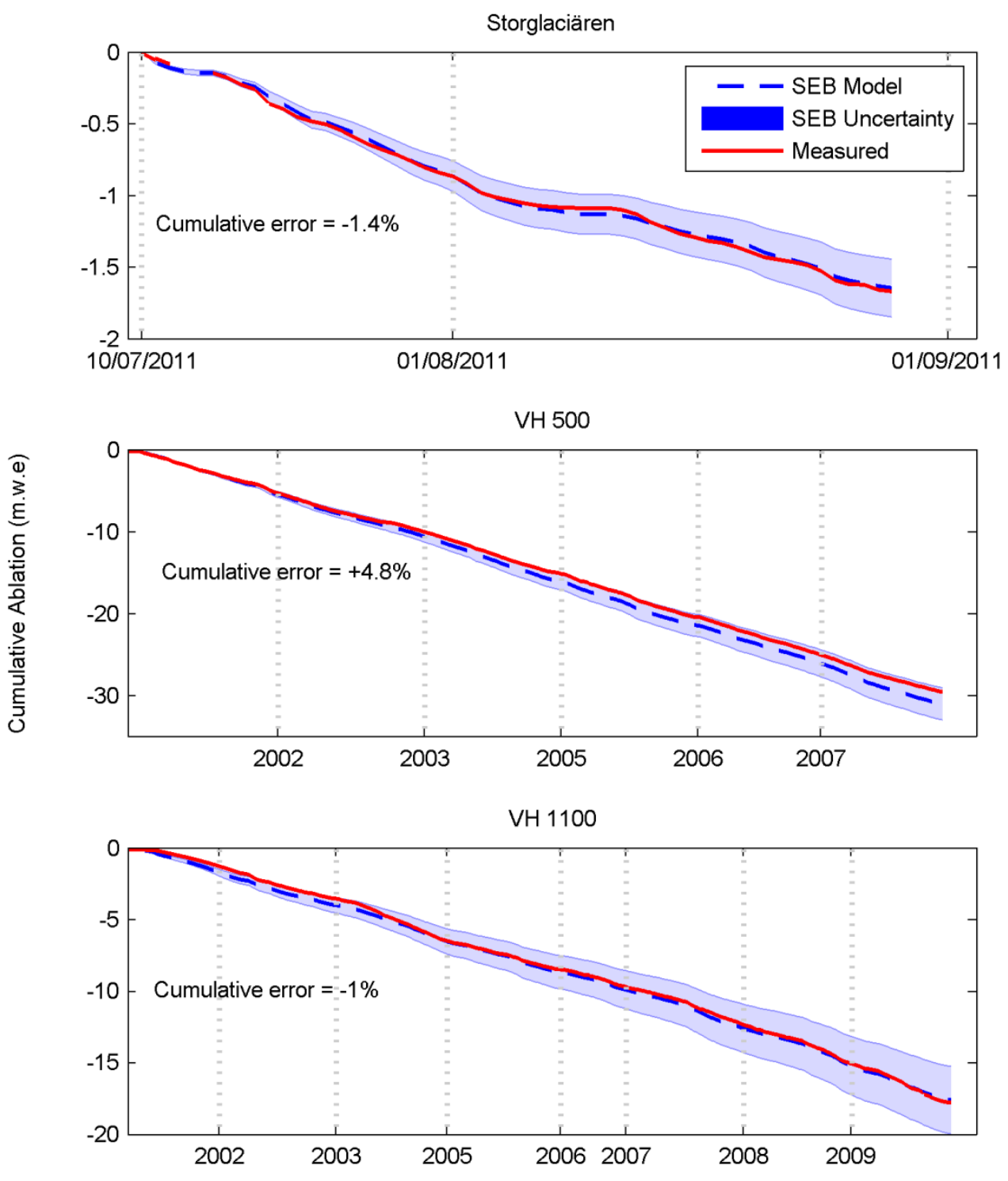

Date 

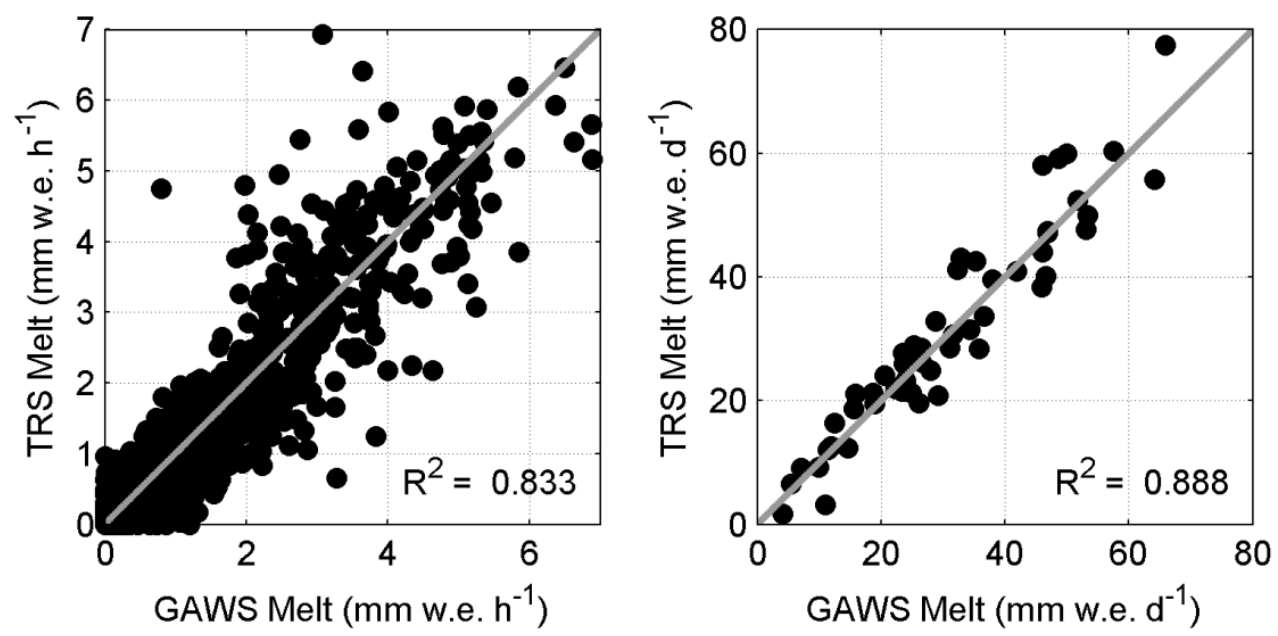

982

983

Figure 3

984

985

986

987

988

989 

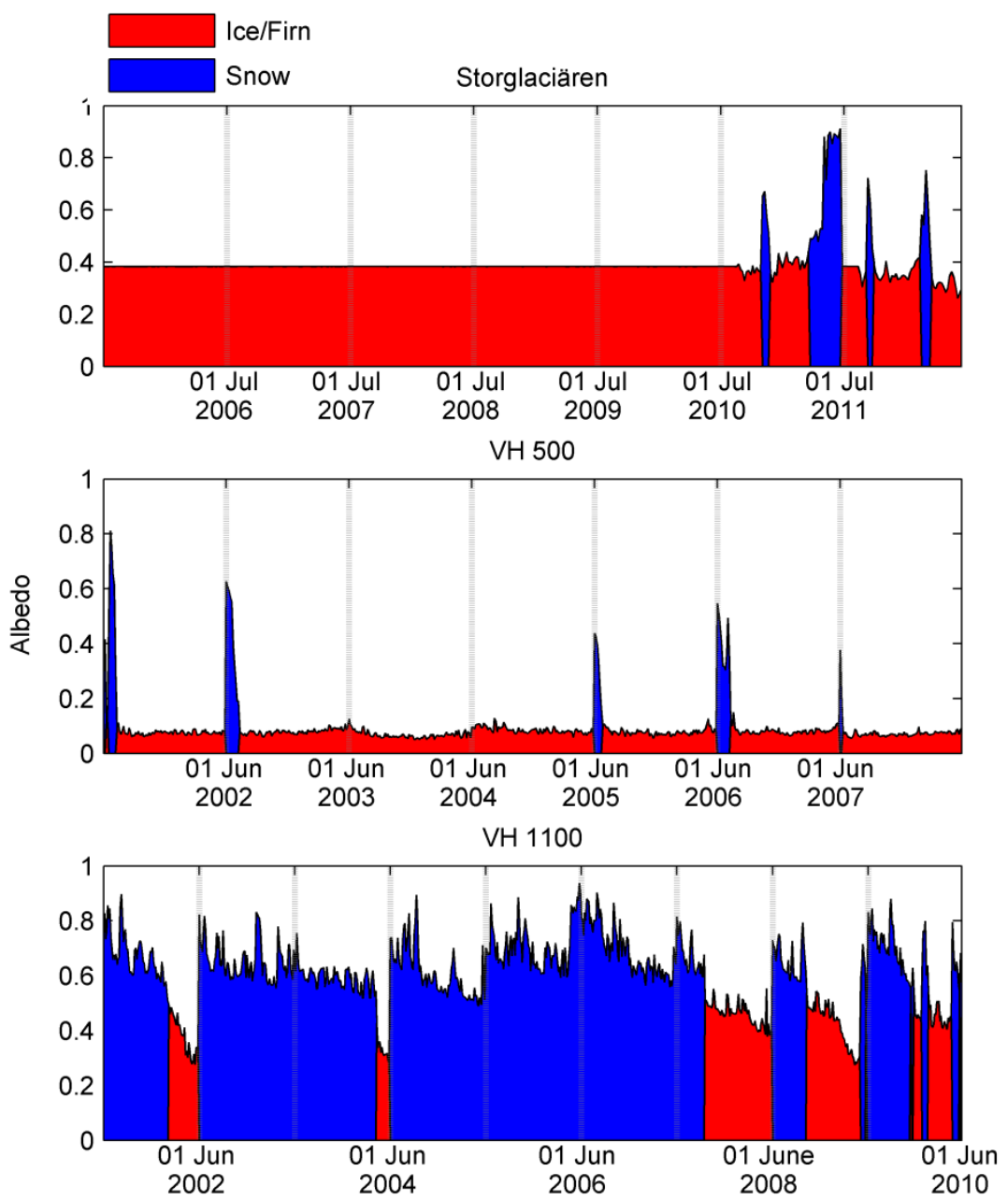

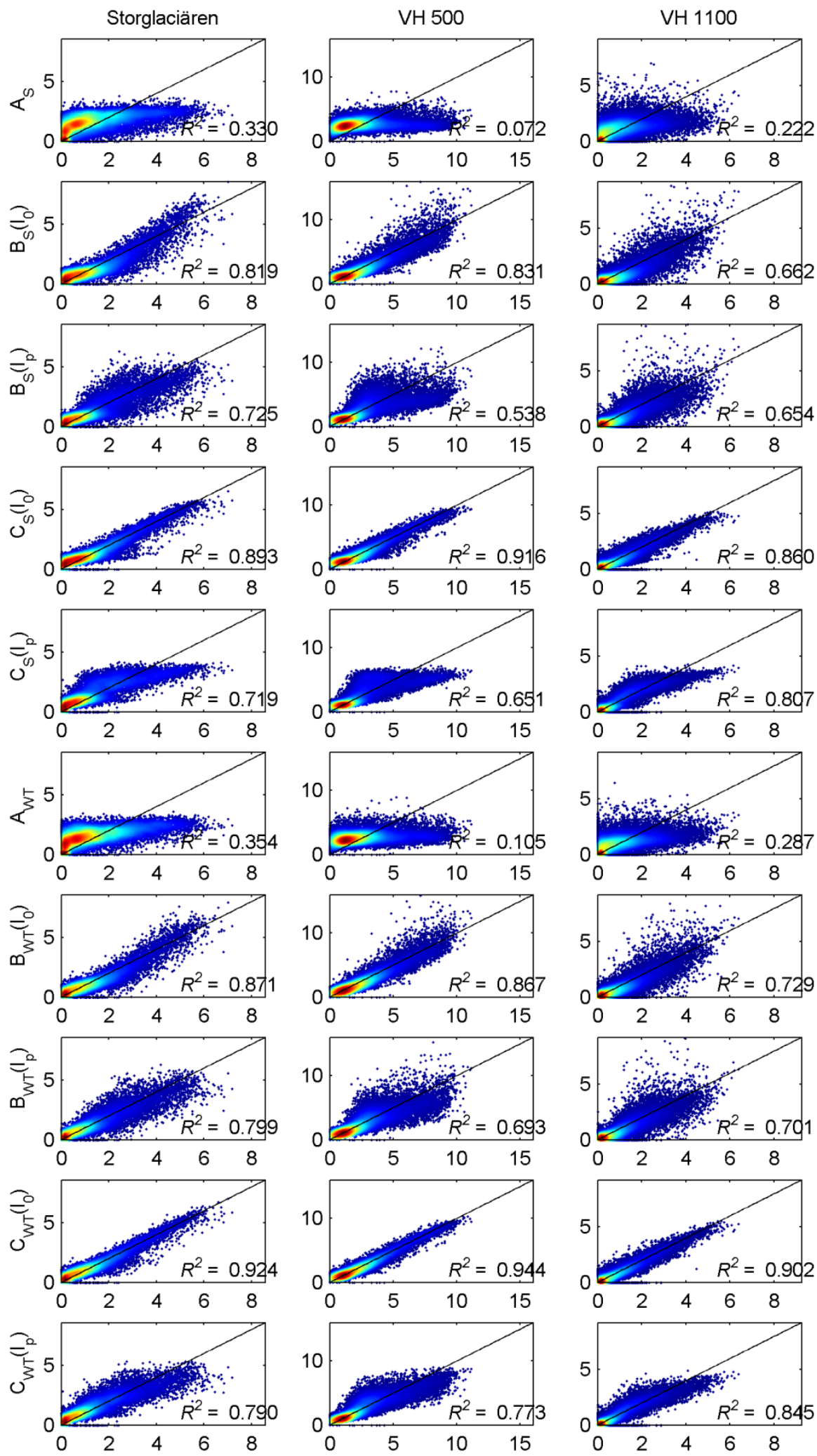

Reference melt ( $\mathrm{mm}$ w.e. $\mathrm{hr}^{-1}$ ) 

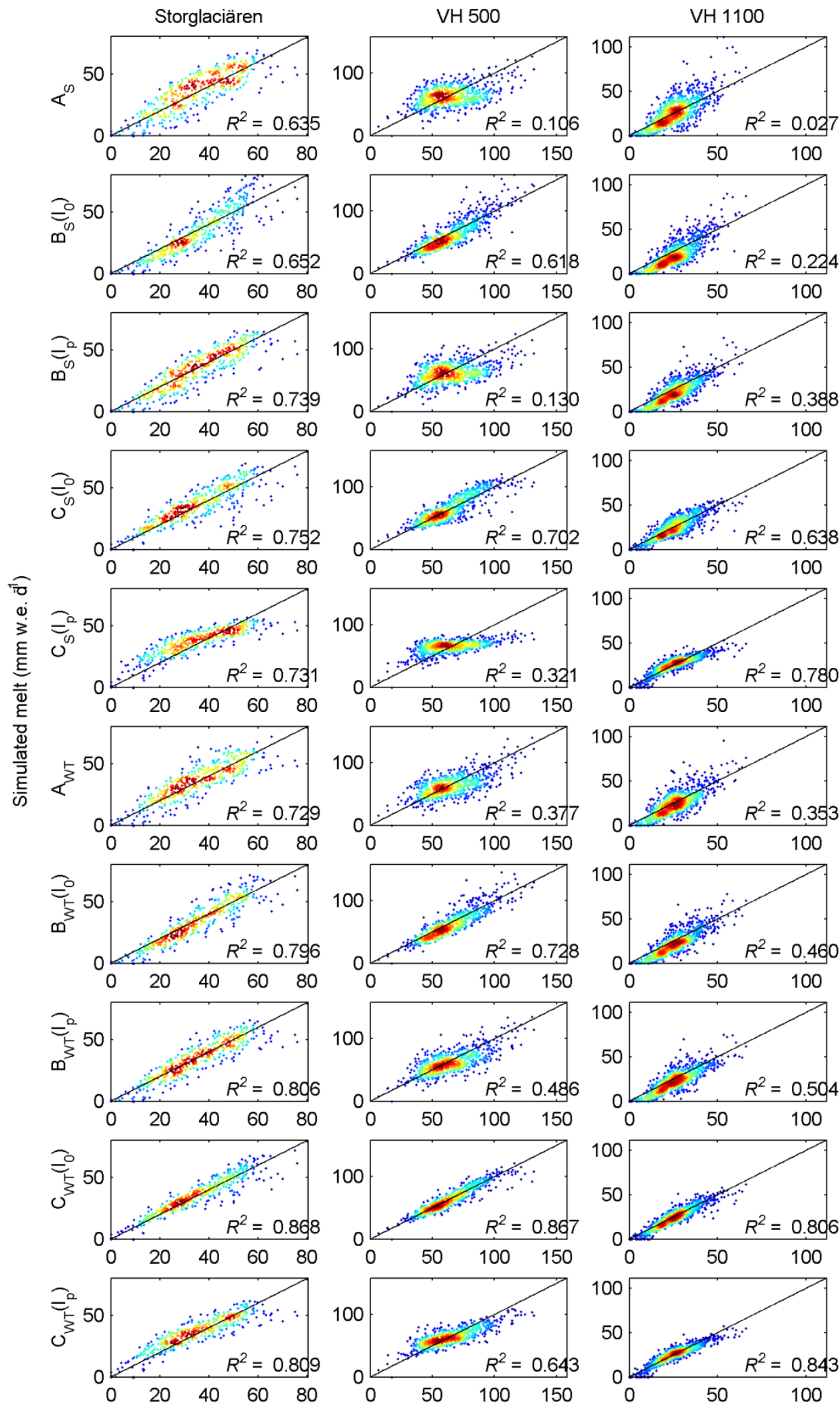

Reference melt (mm w.e. $\mathrm{d}^{-1}$ ) 


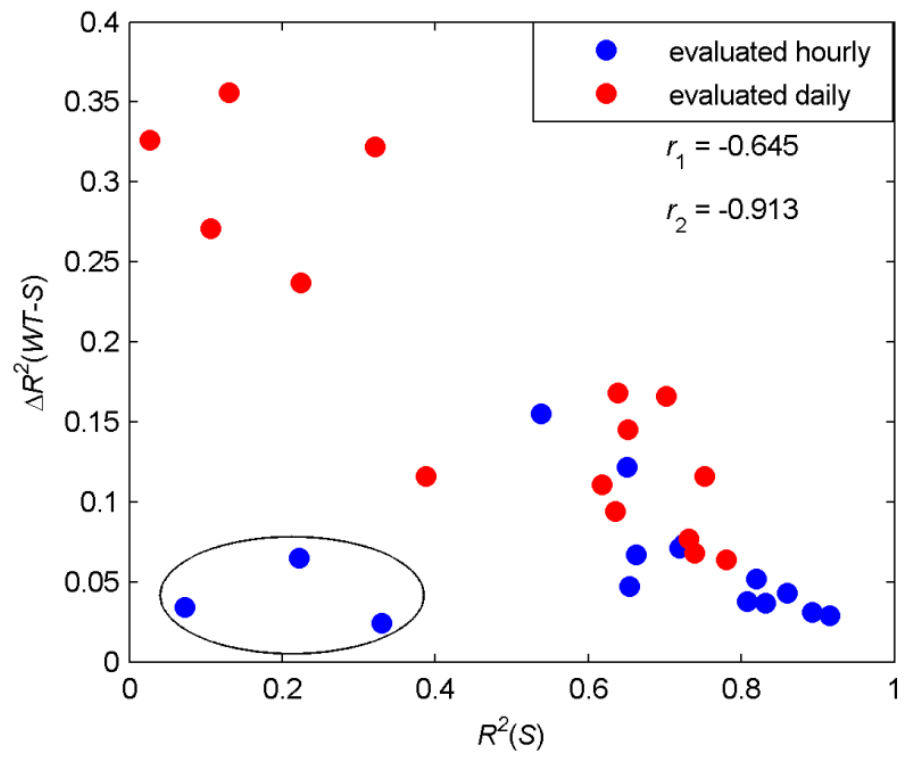

1004

Figure 7

1005

1006

1007

1008

1009

1010

1011

1012

1013 


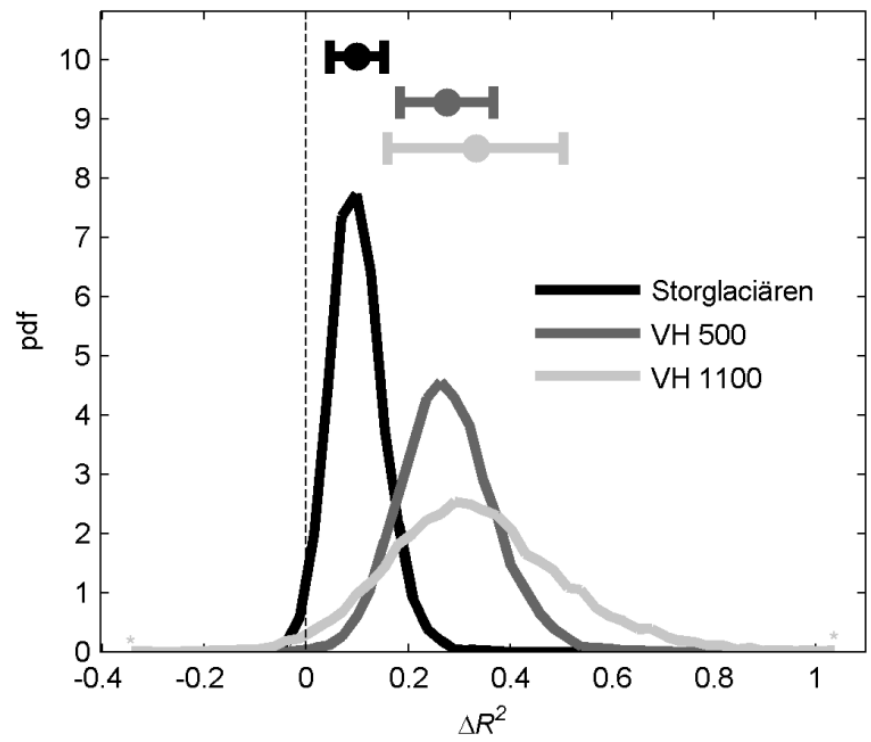

1015

Figure 8 

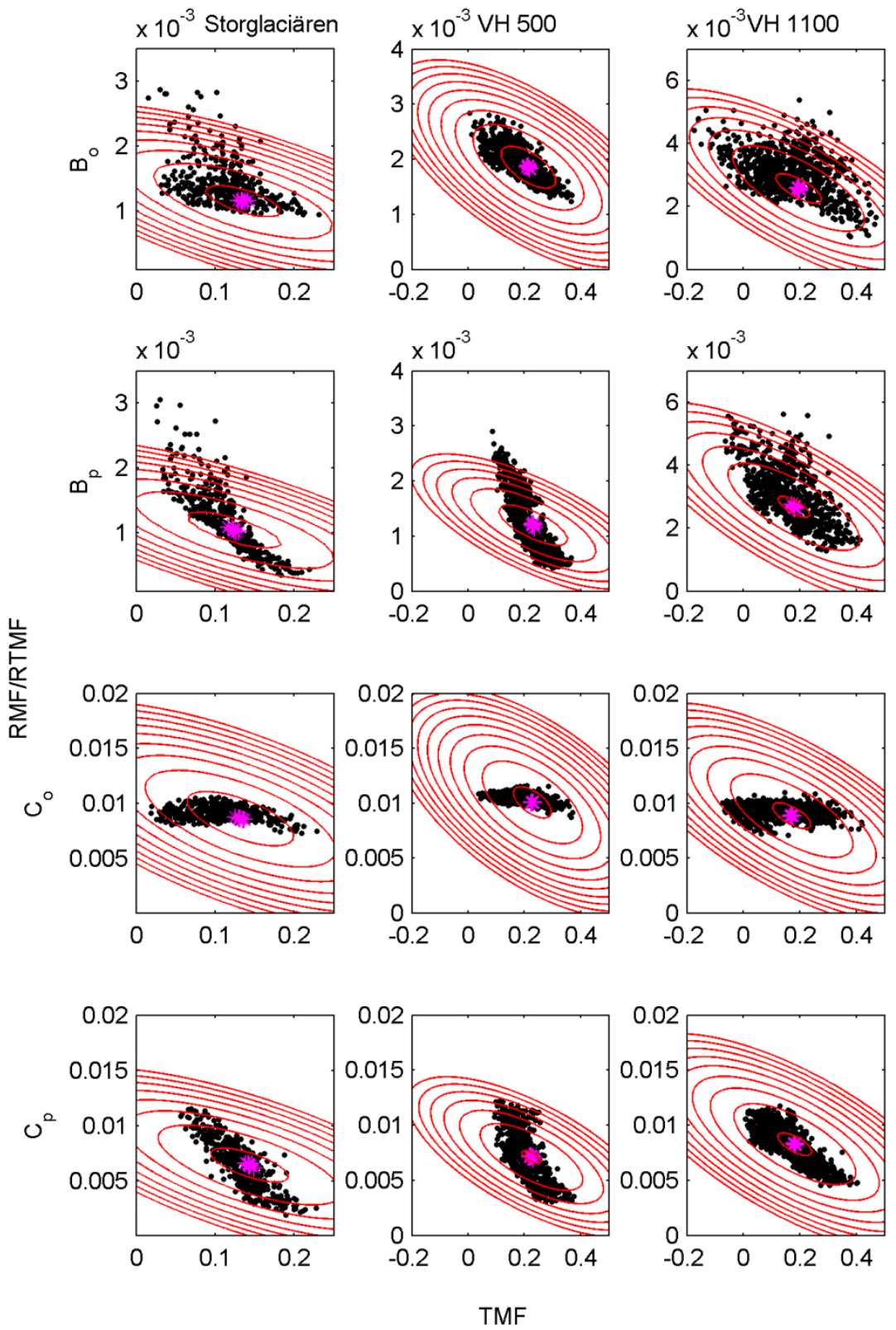

1016

1017

Figure 9 


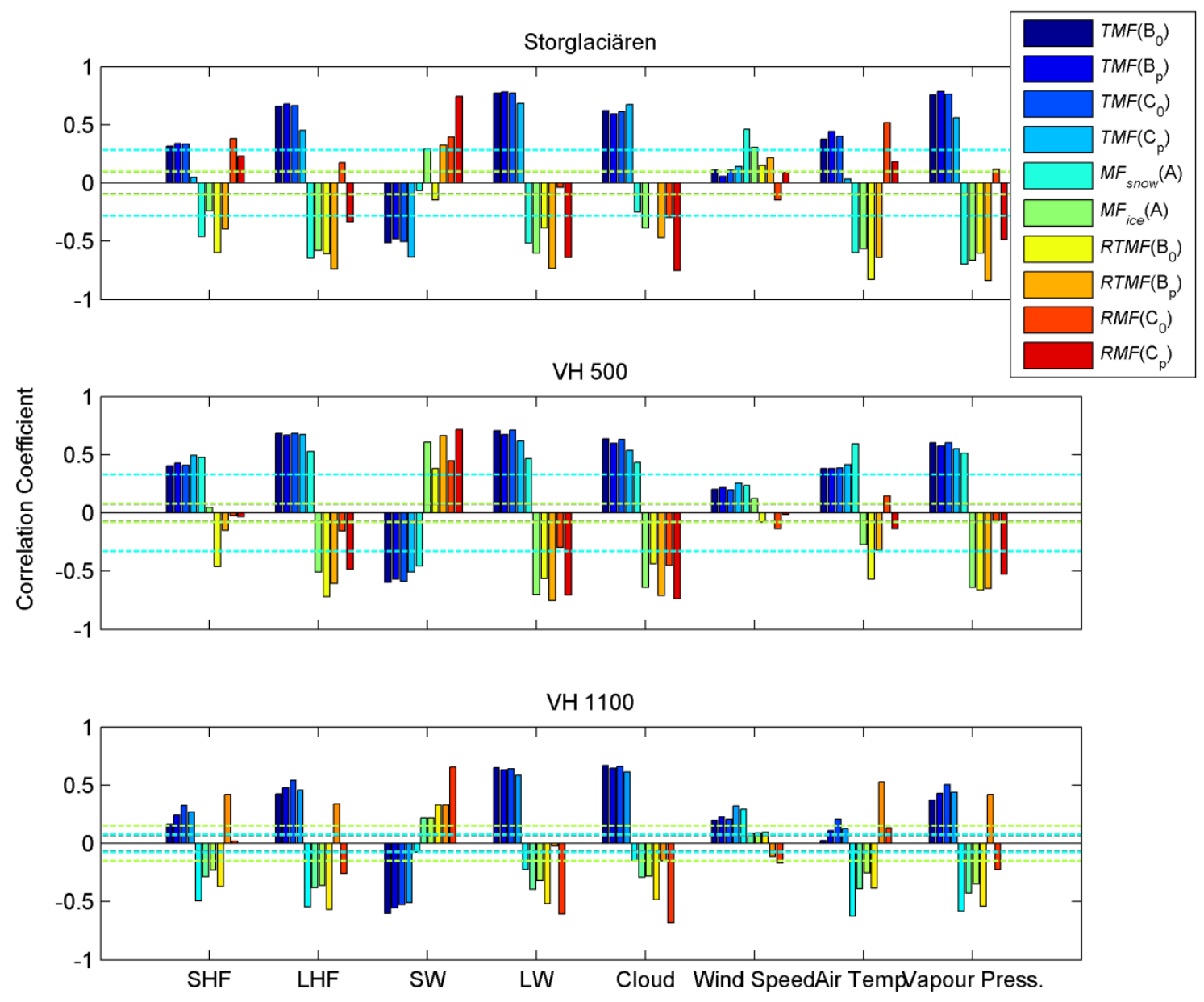

1018

1019

Figure 10

1020

1021 

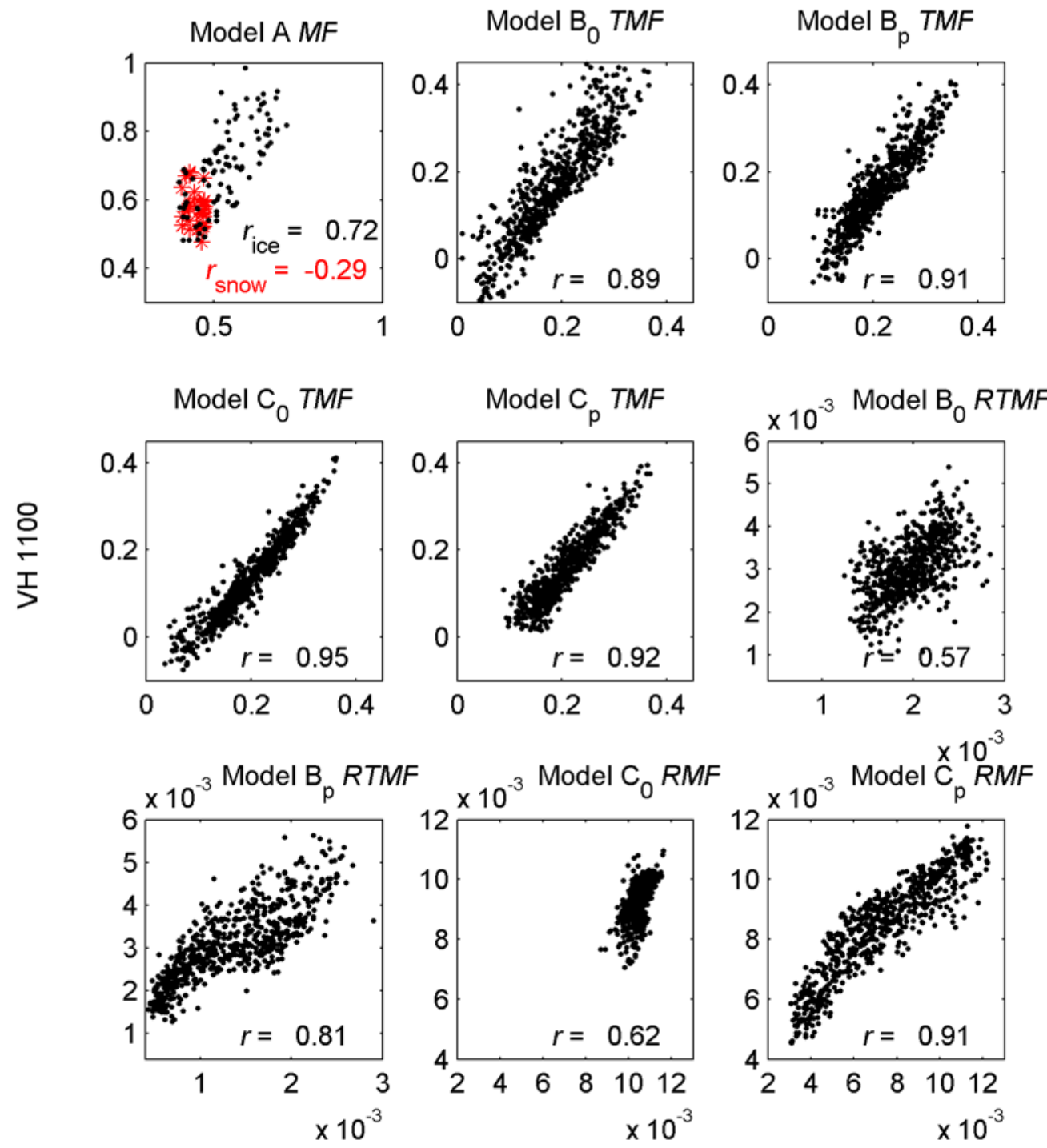

1022

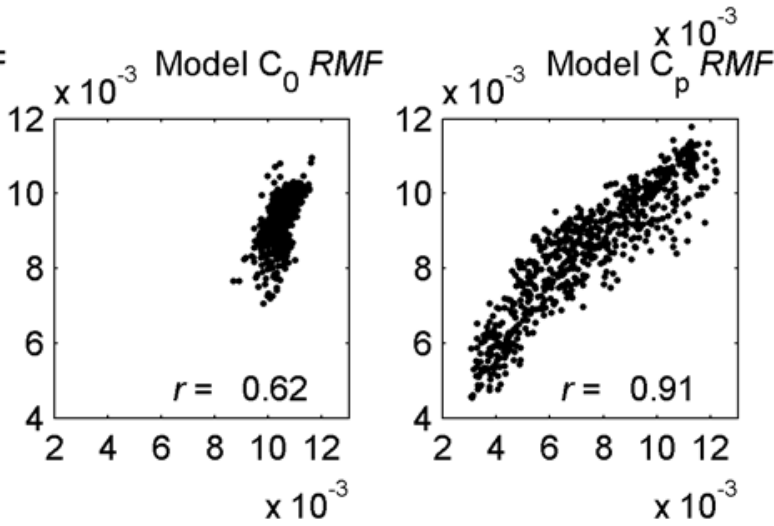

VH 500

1023

Figure 11

1024

1025

1026

1027

1028

1029 